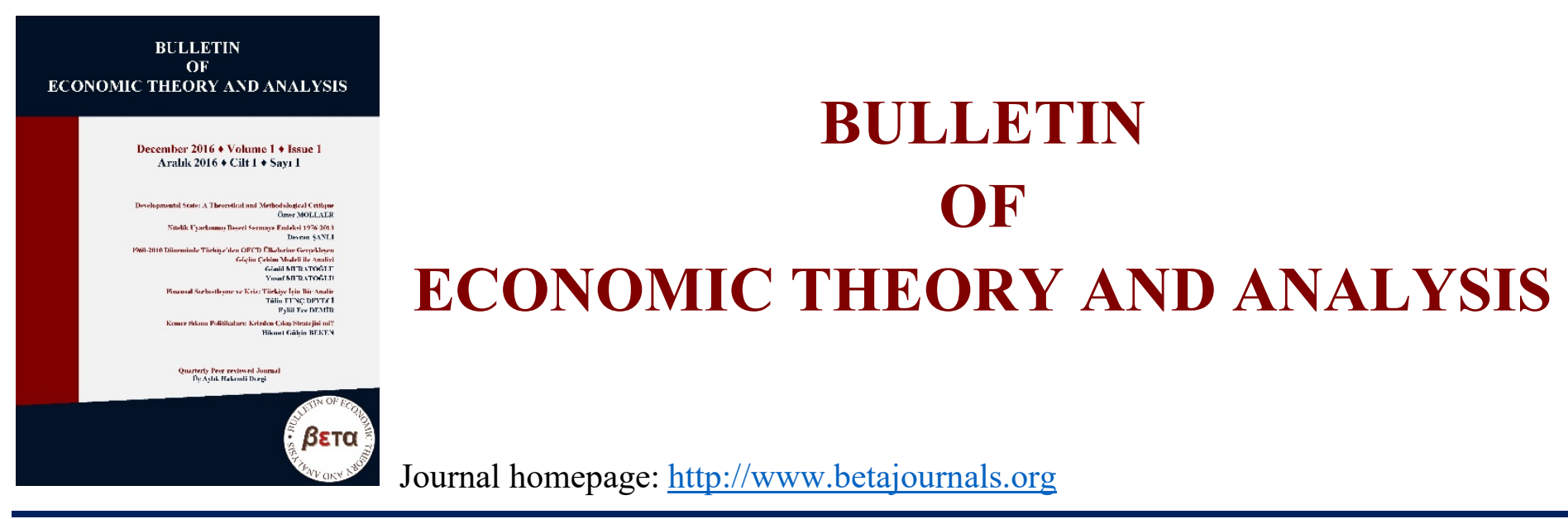

\title{
Türk Bankacılık Sektörü Kredi Riski Yönetiminde Öncü Göstergelerin Belirlenmesi: Sektörel Risk Derecelendirmesi
}

Esra Memduha YAŞAR @ https://orcid.org/0000-0002-0499-073X

\section{Serdar KILIÇKAPLAN ๑ https://orcid.org/0000-0001-8013-0494}

To cite this article: Yaşar, E., M., \& Kılıçkaplan, S. (2020). Türk Bankacılık Sektörü Kredi Riski Yönetiminde Öncü Göstergelerin Belirlenmesi: Sektörel Risk Derecelendirmesi. Bulletin of Economic Theory and Analysis, 5(2), 37- 73.

Received: 04 Jun 2020

Accepted: 20 Oct 2020

Published online: 31 Dec 2020

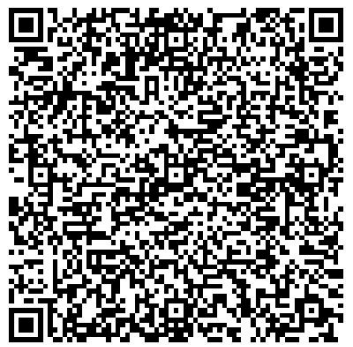




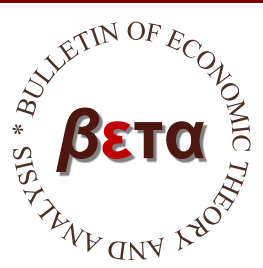

\title{
Bulletin of Economic Theory and Analysis
}

Volume V, Issue 2, pp. 37-73, 2020

http://www.betajournals.org

Original Article / Araştırma Makalesi

Received / Alınma: 04.06.2020 Accepted / Kabul: 20.10.2020

\section{Türk Bankacılık Sektörü Kredi Riski Yönetiminde Öncü Göstergelerin Belirlenmesi: Sektörel Risk Derecelendirmesi}

\author{
Esra Memduha YAȘAR ${ }^{\mathrm{a}}$ \\ Serdar KILIÇKAPLAN ${ }^{\mathrm{b}}$ \\ a Türkiye Kalkınma ve Yatırım Bankası AŞ, Risk Yönetimi, Kıdemli Uzman, İstanbul, TÜRKIYYE \\ (D) https://orcid.org/0000-0002-0499-073X

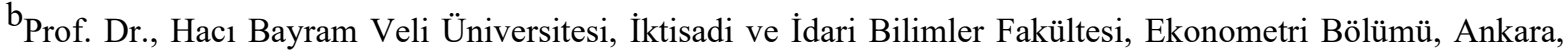 \\ TÜRKIYE @ https://orcid.org/0000-0001-8013-0494
}

\section{ÖZ}

$\mathrm{Bu}$ çalıșmanın amacı, sanayi sektörlerinin mevcut dönem finansal rasyolarından hareketle sektörel risk derecelendirmesi yapmak ve bir sonraki dönem için öncü göstergeler belirlemeye çalışmaktır. Sektörel risk derecelendirmesinde faktör analizi yöntemi kullanılmıştır. 2016-2019 döneminde her yıl için sektörler takipteki krediler rasyosuna göre sıralandığında en iyi performans gösteren Finansal Aracılık, KimyaKimya Ürünleri ve Motorlu Araçlar sektörleri, analiz sonuçlarına göre de ilk sıralarda yer almıştır. Sektörel risk derecelendirmesinde Enerji ve İnşaat sektörlerinin sırasıyla takipteki krediler rasyolarındaki gelişmeler de tutarlıdır. Ayrıca Bankacılık Düzenleme ve Denetleme Kurumu'nun 17 Eylül 2019 tarihli açıklaması, söz konusu iki sektöre ilişkin 46 milyar TL tutarındaki kredinin aslında takip hesaplarında izlenmesi gerektiği yönündedir ve bu açıklama da analiz sonuçlarını teyit eder niteliktedir. Öncü göstergelerin belirlenmesine yönelik olarak faktör analizinde kullanılan yatay kesit verilerine zaman boyutu da eklenerek oluşturulan 2013-2019 dönemine ait veri setine panel veri analizi uygulanmıştır. Her iki analiz sonucunda da anlamlı bulunan Ekonomik Rantabilite, Aktif Kârlılı̆̆ı, Özkaynak Rasyosu'nun birer öncü gösterge olarak değerlendirilebileceği saptanmıştır.

Anahtar Kelimeler

Bankacilik, Risk Yönetimi, Takipteki Krediler, Faktör Analizi, Panel Veri Analizi

JEL Kodu E44, G21, G32, $\mathrm{C} 31, \mathrm{C} 23$

ILETIŞíiM Esra Memduha YAŞAR $₫$ esramemduha.yasar@gmail.com $\Xi^{\prime \prime}$ Hac1 Bayram Veli Üniversitesi, Ekonometri Anabilim Dalı, Doktora Öğrencisi

* Bu makale Esra Memduha YAŞAR'ın doktora tezinden üretilmiştir. 


\title{
Determination of Leading Indicators in Credit Risk Management in the Turkish Banking Sector: Sectoral Risk Rating
}

\begin{abstract}
The aim of this study is to make sectoral risk rating based on the current period financial ratios of the industry sectors and to determine the leading indicators for the next period. Factor analysis method was used in sectoral risk rating. In 2016 to 2019, when the sectors were ranked according to the non-performing loans ratio, the Financial Intermediation, Chemical-Chemical Products and Motor Vehicles sectors, which showed the best performance, took also the best place according to the analysis results. The fact that the Energy and Construction sectors were at the bottom of the rankings of sectoral risk rating showed consistency with the rankings made according to the non-performing loans ratio. In addition, the Banking Regulation and Supervision Agency's announcement dated September 17, 2019 indicates that the loan amounting to TL 46 billion for the two sectors in question should actually be followed in the non-performing loans accounts. This announcement confirms the results of the analysis. In order to determine the leading indicators, panel data analysis was applied to the data set for the 2013-2019 period, which was created by adding the time dimension to the horizontal section data used in factor analysis. As a result of both analyzes, it was determined that Economic Profitability, Return on Assets, Equity Ratio can be evaluated as a leading indicator.
\end{abstract}

Keywords

Banking,

Risk Management, Non-Performing

Loans,

Factor Analysis,

Panel Data Analysis

JEL Classification

E44, G21, G32,

$\mathrm{C} 31, \mathrm{C} 23$

\section{Giriş}

2001 Finansal Krizi sonrasında Türk bankacılık sektöründe başlatılan yapısal yeniden yapılandırma sürecinde BDDK'nın kurulmasıyla hem gözetim ve denetim etkinliği artırılmış hem de sektörü daha etkin ve rekabetçi bir yapıya kavuşturacak yasal ve kurumsal düzenlemelerin gerçekleştirilmesi sağlanmıştır. BDDK yasal ve kurumsal düzenlemelerde uluslararası kabul gören Basel Komitesi'nin yayınlandığı standartları Türk bankacılık sektörüne entegre etmeyi amaçlamıştır. Bu doğrultuda Basel düzenlemelerinin Türk bankacılık sektörüne etkilerini öncelikle “Sayısal Etki Çalışmaları”yla saptayarak, uygulamalara geçiş için yol haritaları belirlemiş ve Türk bankacılık sektörünün uluslararası düzenlemelere uyumunu büyük ölçüde sağlamıştır. Böylece 2001 Finansal Krizi sonrasındaki düzenlemeler ve uygulamalar Türk bankacılık sektörünü, uluslarası platformlarda faaliyet gösteren rekabetçi bir yapıya kavuşturmuştur.

Basel Bankacılık Denetim Komitesi, 1974 yılında İsviçre'nin Basel kentinde Uluslararası Takas Bankası (Bank for International Settlements - BIS) bünyesinde, gelişmiş ülkelerin merkez bankaları ve bankacılık denetim otoritelerinden yetkililerin katılımıyla oluşturulan ve bankacılık konusunda istişari mahiyetli olarak uluslararası standartları yayımlayan komitedir. Basel Komitesi, 
resmi olarak yasal bir statüye veya otoriteye sahip olmamakla birlikte ilgili ülkelerin kamu kurumlarının üye olduğu bir organizasyondur. Komite tarafından ihdas edilen standart ve ilkeler, büyük ölçüde etkili yönlendirici öneriler niteliğinde olup, dünya genelinde kabul görmektedir (BDDK, 2007).

Basel I farklı ülkelerde uygulanan sermaye yeterliliği hesaplama yöntemlerini birbirleriyle uyumlu hale getirmek ve bu konuda uluslararası platformda geçerli olacak asgari bir sektör standardı oluşturmak amacıyla Temmuz 1988 'de yayımlanmıştır. Basel I kurallarına yönelik en büyük eleştiri “OECD kulüp kuralı”na yönelikti (BDDK, 2007). Bu uygulama, OECD üyesi ülkelerin diğer ülkelere göre düşük riskli ve hatta risksiz olarak kabul edilmesine dayanmaktaydı. Ülkemizde 2005 yılında uygulamaya başlanan Basel II kurallarında, Basel I'de yer alan kredi riski ölçümündeki OECD kulüp kuralı kaldırılmış, bunun yerine kredi derecelendirmesine öncelik verilmiştir. Basel II kurallarına göre kredi riski hesaplaması için farklı yöntemlerin kullanılabilmesi mümkün olmuştur. Kredi riski ölçümünde risk ağırlıkları, standart yöntemde; bağımsız derecelendirme kuruluşlarının verdiği notlara göre, temel içsel derecelendirme yönteminde; kurumların içsel derecelendirme modellerine göre, gelişmiş içsel derecelendirme yönteminde ise kurumların yine içsel olarak hesaplayacakları temerrüt olasılıkları (TO), temerrüt halinde kayıp (THK) ve temerrüt anındaki risk tutarlarına (TART) göre belirlenecektir. Kredi riski ölçümünde içsel model ancak BDDK'dan onay alındığında kullanılabilmekte, standart yöntemde ise derecelendirme notu bulunmadığında Basel tarafından öngörülen risk ağırlıkları kullanılmaktadır. Kredi riski hesaplamasında derecelendirmeye dayalı yaklaşımlar yasal mevzuat kapsamında zorunlu olmamakla birlikte, Basel düzenlemelerindeki gelişmelere bağlı olarak gelecek dönemde zorunluluk haline gelebileceği öngörülmektedir (BDDK, 2005).

Türk bankacılık sektörü için kritik önem taşıyan en güncel düzenlemelerden birisi de, 01.01.2018 tarihinde uygulanmaya başlanan "Kredilerin Sınıflandırılması ve Bunlar İçin Ayrılacak Karşılıklara İlişkin Usul ve Esaslar Hakkında Yönetmelik” ile "Türkiye Finansal Raporlama Standardı (TFRS) 9 Finansal Araçlar Standardı”dır. TFRS 9 uygulamasının getirdiği en önemli yenilik, “gerçekleşen zarar modeli”nin yerini “beklenen zarar modeli”nin almasıdır.

Beklenen Kredi Zararı (BKZ) modeli, kredilerin temerrüt olasılıkları (TO), temerrüt halinde kayıp (THK) ve temerrüt anındaki risk tutarı (TART) dayalı bir modeldir. Basel uygulamalarındaki kredi riski gelişmiş içsel derecelendirme yöntemi ile TFRS uygulamasındaki Beklenen Kredi 
Zararı modeli hesaplamaları önemli ölçüde benzeşmekle birlikte aynı parametrelerin farklı yöntemlerle hesaplanmakta olduğunu söylemek mümkündür. Bu iki modellemede de geleceğe yönelik makroekonomik öngörülerin modellere yansıtılması gerekmektedir. Aslında ulaşılmak istenen, makroekonomik gelişmeler ile kredi portföyü hatta kredi kullandırılan karşı taraf arasındaki ilişkinin saptanması ve makroekonomik öngörüler çerçevesinde gelecek dönemde kredi portföyünün nasıl etkileneceğini hesaplamalara dâhil etmektir.

Önümüzdeki dönemde, bankaların hem sermaye yeterlilik rasyosunun bir bileşeni olarak kredi riskinin ölçülmesinde hem de TFRS 9 uygulaması kapsamında karşılık tutarının hesaplanmasında içsel model kullanmaları kaçınılmaz olacaktır. Kullanılacak içsel modelin sağlıklı sonuçlar üretmesi, gerek bankanın kredi riski için ayırması gereken sermaye miktarını gerekse kârından vazgeçerek ayırdığı karşılık miktarını optimum düzeyde belirlemesine katkı sağlayacaktır. Dolayısıyla bankaların en düşük sermayeyle en yüksek kârlılığa ulaşma temel hedefi doğrultusunda, sağlıklı sonuçlar üreten içsel model kullanımı kritik öneme sahip olacaktır. Kredi portföyünde yaşanabilecek sıkıntılar için yeterli miktarda sermaye ve karşılık bulundurmak, bankaların zorluk çekmeden bu kredileri çözüme kavuşturabilmesini sağlayacaktır. Ancak gereğinden fazla bulundurulan sermaye ve ayrılan karşılık miktarı da bankalar için ekstra maliyet yaratacaktır. Diğer taraftan sağlıklı bir içsel model kullanımı, gerek kredi politikalarının belirlenmesinde gerekse kredi riskinin etkin bir şekilde yönetilmesinde karar mekanizmalarını destekleyici en önemli unsurlardan biri olacaktır.

Bu noktadan hareketle çalışma, sektörel risk derecelendirmesi uygulamasıyla içsel model çalışmalarına katkı sağlamak amacı da taşımaktadır. Sektörel risk derecelendirmesi, sektörlerin birbirlerine karşı risklilik düzeyine göre sıralandırılmasını ifade etmektedir. Çalışmada çok değişkenli analiz tekniklerinden yatay kesit analizi olan faktör analizi yöntemiyle sektörel risk derecelendirmesi yapılmıştır. Sektörel risk derecelendirmesiyle takipteki krediler rasyolarına göre sektörel farklılaşmayı ortaya koyan değişkenler saptanmıştır. Öncü göstergelerin belirlenmesi amacıyla da panel veri analizi yapılmıştır. Böylece sektörel risk derecelendirmesinde elde edilen yüksek açıklama gücüne sahip olan finansal rasyoların birer “öncü gösterge” olarak değerlendirilebilmesi araştırılmıştır. Öncü gösterge kavramını bir gelişimi, oluşumdan daha önce gösteren nicelikler veya değerler olarak tanımlamak mümkündür. Bu çalışma kapsamında bir 
dönem önce (t-1) her sektör için hesaplanan "öncü gösterge” niteliğindeki rasyoların, bir sonraki dönem (t) sektörlerin risklilik durumuna yönelik bilgi vermesi öngörülmektedir.

Çalışma giriş ve sonuç bölümleri ile birlikte altı bölümden oluşmaktadır. İkinci bölümde literatür taramasına, üçüncü bölümde ise analizlerde kullanılacak veri seti ve yönteme yer verilmiştir. Dördüncü bölümde sektörel risk derecelendirmesi, beşinci bölümde de öncü göstergelerin belirlenmesi ana başlıkları altında uygulanan yöntemlerle ilgili bilgi verilmiş, analiz sonuçları ve sonuçlara ilişkin değerlendirmeler paylaşılmıştır. Çalışma genel değerlendirmeleri içeren sonuç bölümüyle tamamlanmıştır.

\section{Literatür Taraması}

Sektörel risk derecelendirmesi konu başlı̆̆ı "sektör" ve "risk derecelendirmesi” olmak üzere iki temel alt başlığı içermektedir. Bu çalışmada, sektör kapsamı olarak "Türkiye sanayi sektörü” belirlenmiştir. Yapılan literatür taramasında, Apan, İslamoğlu (2018), Kılıç, Güler (2019) ve Çolak (2019) tarafından yapılan araştırmaların, seçilmiş sektörlerde borsaya kote olan firmaların mali yapıları ve hisse senedi fiyatlarının gelişimi arasındaki ilişki üzerine olduğu ve genel olarak sektörlere yönelik araştırmaların bu amaç doğrultusunda yapıldığı saptanmıştır. Çalışmalarda genellikle finansal rasyolarla firmaların faaliyette bulunduğu sektörün mali analizi yapılmakta ve hisse senedi fiyat gelişimiyle elde edilen analiz sonuçlarının tutarlılığı değerlendirilmektedir. İmalat sanayine yönelik bir çalışmada Demirci (2017) Türkiye Cumhuriyeti Merkez Bankası (TCMB) sektör bilançolarını kullanarak panel veri analiziyle imalat sanayi sektöründe seçilmiş sektörlere ilişkin kârlılığın belirleyicilerini tahmin etmeye çalışmıştır. Diğer bir çalışmada Öcal ve Akın (2018) TCMB sektör bilançolarından hareketle, seçilmiş sektörler ile temel makroekonomik büyüklükler arasındaki ilişkileri regresyon analiziyle incelemiştir. İltaş (2016) ise çalışmasında panel veri analiziyle TCMB sektör bilançolarından seçilmiş sektörlerin işletme sermayesi gereksinimini etkileyen değişkenleri saptamaya çalışmıştır.

$\mathrm{Bu}$ çalışmanın diğer alt başlığı olan "risk derecelendirmesi”" konusunda yapılan literatür taramasında, bankalar üzerinde yoğunlaşmış ulusal ve uluslararası birçok çalışmaya rastlanmıştır. $\mathrm{Bu}$ çalışmalar genellikle ABD'de denetim otoriteleri tarafindan geliştirilen CAMELS Derecelendirme Sistemi ${ }^{1}$ kullanılmıştır. Türk bankacılık sektöründe Gündoğdu (2017), Erdoğan,

\footnotetext{
${ }^{1}$ CAMELS Derecelendirme Sistemi'nde "C" (Capital Adequacy) Sermaye Yeterliliği, "A" (Asset Quality) Varlık Kalitesi, "M" (Management Quality) Yönetim Kalitesi, "E” (Earnings) Kazançlar, "L” (Liquidity) Likidite Durumu
} 
Karaca (2018) ve Uslu (2019) tarafından yapılan çalışmalarda CAMELS kapsamında belirlenmiş finansal rasyolar hesaplanmış ve bu rasyolar ağırlıklandırılarak her banka için bir derecelendirme notu belirlenmiştir. Yine bankalar üzerinde yoğunlaşan Tosuner, vd. (2002) ve Atan (2002) çalışmalarında, çok değişkenli analiz tekniklerinden faktör analiziyle, bankaların finansal rasyoları kullanılarak sıralanması amacını taşımıştır. Bu çalışmaların yapıldığı dönemde Türk bankacılık sektöründe Tasarruf Mevduatı Sigorta Fonu'na devrolan bankalar, kontrol verisi olarak kullanılmış ve analiz sonucunda siralamanın alt siralarında yer alan bankaların TMSF'ye devredilip devredilmediği araştırılmıştır. Yine aynı kontrol verisine dayalı olarak yapılan çalışmalarda çok değişkenli analiz tekniklerinden diskriminat analiziyle iyi banka-kötü banka ayrımı yapılmaya çalışılmıştır.

Sonuç olarak literatür taramasında sanayi sektörlerinin tamamını ele alarak finansal rasyoları üzerinden sektörlerin risklilik düzeyini belirlemeye yönelik bir çalışma bildiğimiz kadarıyla bulunmamaktadır. Bunun yanında risk derecelendirmesi konusunda yapılan çalışmaların daha çok bankacılık sektörüne yoğunlaşması sanayi sektörüne yönelik bir risk derecelendirme çalışması olan bu çalışmayı öne çıkaran bir diğer unsurudur.

\section{Veri Seti ve Yöntem}

Çalışmada kullanılan sektörel mali tablolar Sanayi ve Teknoloji Bakanlığı Girişim Bilgi Sistemi'nden temin edilmiştir. Literatür taramasında sanayi sektörlerine yönelik çalışmalarda kullanılan veri setlerinin $\mathrm{TCMB}^{2}$ sektör bilançoları olduğu gözlenmiştir. TCMB tarafından en son yayınlanan sektör bilançolarında (2014-2016 dönemi) 8.721 firmanın verisinin kullanıldığı açıklanmıştır (TCMB, 2017). Sanayi ve Teknoloji Bakanlığg Girişim Bilgi Sistemi 'nde ise 2016 yılı özelinde 1,2 milyon firma bilgisi kullanılmış, en güncel 2018 yılı verilerinde ise firma sayısı

ve "S" (Sensitivity to Market Risk) Piyasa Riskine Duyarlılık faktörlerini temsil eden finansal rasyolarla bankalar değerlendirilmektedir.

${ }^{2}$ TCMB sektör bilançolarının ilgili sektördeki firmaların gönüllü katılımı ve desteğinin yanında, yıllık mali tablo verileriyle hazırlanmaktadır. TCMB internet sitesinde yapılan açıklamaya göre idari kayıtlara dayalı olarak üretilmesi ve kapsamının reel sektörde faaliyet gösteren tüm firmaları içerecek şekilde 16 Eylül 2020 tarihinde yayınlanması plânlanmaktadır.

${ }^{3}$ 03/06/2011 tarihli ve KHK/635 karar sayılı Sanayi ve Teknoloji Bakanlığının Teşkilat ve Görevleri Hakkında Kanun Hükmünde Kararname ile Bakanlığa verilen görev kapsamında, Sanayi ve Teknoloji Bakanlığı bünyesinde "Girişim Bilgi Sistemi (GBS)" geliştirilmiştir. Sistemin amacı; "Makro ve mikro düzeyde, kamu kesimindeki politika yapıcılar ile karar alıcılara, ekonomi politikaların tasarlanması, uygulanması ve etkinlik ölçümü için doğru ve güvenilir bilgilerin sunulacağı bir ortam sağlamak, ekonomi analizleri çalışmalarında kullanılmak üzere, üniversitelere, enstitülere, sivil toplum kuruluşlarına, özel araştırma kuruluşları ile bireysel araştırmacılara doğru ve güvenilir bilgiler sunmak ..." şeklinde ifade edilmektedir. 
1,35 milyona ulaşmıştır. Dolayısıyla bu çalışmada sanayi sektörüne ilişkin temsil gücü yüksek ve mümkün olabilecek en güncel verilerin bulunduğu Girişimci Bilgi Sistemi (GBS) verileri kullanılacaktır.

Girişimci Bilgi Sistemi’nde 17 genel sektör ve 24 imalat alt sanayi sektörü olmak üzere toplam 41 sektöre ilişkin bilanço ve gelir tablosu bulunmaktadır. Genel sektörlerden "Diğerleri" başlığı altında birçok alt sektör birleştirildiğinden, imalat sanayi alt sektörlerinden de "Kok Kömürü ve Rafine Edilmiş Petrol Ürünleri İmalatı"na ait mali tablolarda birçok veri gizlendiğinden bu iki sektör analiz dışında bırakılmıştır.

Her bir sektöre ilişkin mali tablolar, o sektörde faaliyet gösteren firmaların mali tablolarının toplulaştırılmasından oluşmaktadır. Bu çalışmada her sektör bir firma gibi değerlendirilecektir. Böylece her sektörün mali tablolarından hareketle o sektöre ait finansal rasyolar hesaplanacak ve bu rasyolar sektörel risk derecelendirmesi analizinde kullanılacaktır. Mali tabloların yıl içerisinde yaşanan makroekonomik gelişmelerin etkilerini yansıttığg bir gerçektir. Sektörel gelişmeler makroekonomik gelişmelerden bağımsız düşünülemeyeceği gibi her sektörün makroekonomik gelişmelerden etkilenme yönü ve derecesi farklılaşmaktadır. Örneğin, ekonominin daralma dönemlerinde genel olarak sektörlerin olumsuz etkileneceği öngörülse de, ihracata dayalı üretim yapan firmaların, hatta kur avantajı da elde etmeleri halinde, ihracat hacimlerini artırmak suretiyle bu süreçten olumsuz etkilenmek bir kenara kârlı bile çıkabileceği düşünülmektedir. Bu boyutuyla da çalışmanın yalnızca sektörlerin birbirlerine göre durumu üzerine değil, genel makroekonomik gelişmelerin sektörel etkileri üzerine de fikir vermesi beklenmektedir.

İlgili literatürde uluslararası kabul görmüş CAMELS Derecelendirme Sistemi kapsamında bankaların finansal durumunu ortaya koyacak finansal rasyoların belirlendiği ve bankacılık sektörü risk derecelendirmesi çalışmalarında da bu finansal rasyoların kullanıldığı saptanmıştır. Sanayi sektörüne yönelik çalışmalarda ise genel olarak firma mali analizine temel teşkil eden rasyolar kullanılmıştır. Bu çalışmada her bir sektöre ait mali tabloların toplulaştırılmış firma finansal rasyoları olduğu düşünüldüğünde, mali analizde kullanılan standart rasyoların kullanılmasının uygun olacağı düşünülmektedir. Ancak sektörlerin farklılaşan yapısal özelliklerine dayanan finansal rasyoların, risk derecelendirmesinde kullanılmasının uygun olmayacağı değerlendirilmiştir. Bu rasyolar, özellikle, maddi duran varlıkları ve stokları içeren finansal rasyolardır. Böylece, örneğin, yüksek miktarda maddi duran varlık yatırımı gerektiren bir sektörün 
veya yüksek miktarda stokla çalışması gereken bir sektörün, diğer sektörlerden bu özellikleri bakımından ayrışması engellenmiştir.

23 imalat sanayi alt sektörü sektörel mali tablolardan hareketle "Likidite Rasyoları", "Devir Hızı Rasyoları”, “Mali Yapı Rasyoları”, “Kârlılık Rasyoları” ve "Büyüme Rasyoları” olmak üzere beş başlıkta toplanabilecek 59 finansal rasyo hesaplanmıştır. Analizde finansal rasyo kullanılması, büyüklük itibariyle homojen olmayan sektörel mali tablolardan, homojen bir veri seti elde edilebilmesini sağlamıştır.

Faktör analizi sonuçlarının sağlıklı sonuçlar üretip üretmediğini araştırmak için kontrol verisi olarak "sektörel takipteki krediler rasyoları" kullanılmıştır. Türk bankacılık sektöründe sektörel takipteki kredilere yönelik veriler Bankacılık Düzenleme ve Denetleme Kurumu (BDDK) ve Türkiye Bankalar Birliği Risk Merkezi tarafından yayınlanmaktadır. BDDK tarafından yayınlanan veri setindeki sektör sınıflaması ile Sanayi ve Teknoloji Bakanlığı "Girişim Bilgi Sistemi (GBS)"nde alınan mali tabloların sektör sınıflaması örtüşmemektedir. Dolayısıyla bu çalışmada Türkiye Bankalar Birliği Risk Merkezi verileri kullanılmıştır. Türkiye Bankalar Birliği Risk Merkezi tarafından yayınlanan sektörel takipteki krediler rakamlarından hareketle sektörel takipteki krediler rasyoları hesaplanmıştır. Hesaplanan rasyolara göre sektörler en küçük rasyodan büyüğe doğru sıralandırılmıştır. Sektörel risk derecelendirmesinde ise en yüksek puanı alarak en az riskli kabul edilen sektörden, en yüksek riskli sektöre doğru da sıralama yapılacaktır. Böylece sektörlere yönelik iki ayrı sıralama elde edilecek ve bu iki sıralama karşılaştırılarak, yapılan sektörel risk derecelendirmesinin sağlıklı sonuçlar üretip üretmediği incelenecektir.

TFRS 9, kredilerin sınıflandırılmasına ve kredi karşılıklarının ayrılmasına yönelik bir uygulamadır. Kredilerin sınıflandırılmasına yönelik olarak, daha önce bankaların "grup" adı altında sınıfladıkları varlıklarını, "sepet” adı altında sınıflandırmasını öngörmektedir. Sepetlendirme ölçütlerinin genel çerçevesi "Kredilerin Sınıflandırılması ve Bunlar İçin Ayrılacak Karşılıklara İlişkin Usul ve Esaslar Hakkında Yönetmelik” ile belirlenmiş, ancak bankaların sepetlendirmeye yönelik, Yönetmelik hükümlerine aykırı olmamak kaydıyla, daha öznel ölçütler belirleyebilmeleri de mümkün kılınmıştır. Yönetmeliğe göre canlı krediler Sepet 1'de, yakın izleme kapsamındaki krediler Sepet 2'de, takipteki krediler ise Sepet 3'te izlenecektir.

Bir firmanın mali durumunun bozulması ve kredi geri ödeme sürecinde sıkıntı yaşamaya başlamasıyla kredisinin takip hesaplarına aktarılması arasında belirli bir süre geçmesi 
beklenmektedir. Firma kredi ödemelerini düzenli yapmakta ve finansal güçlük durumunu gösteren herhangi bir belirti bulunmuyorsa kredi, bankaca canlı krediler olarak tanımlanan Sepet 1'de izlenmektedir. Kredi ödemesinde 30 günü aşan bir gecikme yaşanırsa ve/veya firmanın finansal güçlük yaşadığına dair bankaca saptanan durumlar varsa kredi yakın izleme olarak tanımlanan Sepet 2 altında izlenmeye başlanmaktadır. Kredi ödemesinde 90 günü aşan gecikme yaşanırsa ve/veya banka firmanın borcunu kesin ödeyemeyeceğine kanaat getirirse kredi, takipteki kredilerin yer aldığı Sepet 3'e intikal edecektir ve bu krediler takipteki krediler rasyosu hesaplamasına dahil edilecektir. Örneğin, üçer aylık sıklıkla kredi geri ödemesi bulunan bir firmanın kredisi, finansal güçlük durumuna düştükten ve kredi ödemesini asgari 90 gün geciktirdikten sonra takip hesaplarına intikal edecektir. Dolayısıyla, bir dönem kredi ödemesi (90 gün) ve yasal gecikme gün sayısı (90 gün) beraber düşünüldüğünde, kredinin takip hesaplarına intikali en az altı aylık (180 gün) bir süreyi kapsayacaktır. Ayrıca ilk kredi taksitinin gecikmesi sonrasında banka firmayla iletişime geçecek ve durum saptaması yapıldıktan sonra kredinin ertelenmesi, yeniden yapılandırılması gibi farklı yaklaşımlar gündeme gelebilecektir. Kredi ertelemesi ve yeniden yapılandırmaya yönelik vadelerin ve koşulların belirlenmesinde birçok faktör rol oynamaktadır. Bu faktörlerin başlıcaları olarak; firmanın finansal durumu, kredinin teminatı ve bankanın finansal durumu sayılabilir. Kredi ertelemesi/yapılandırması her ne vade ve koşulda yapılırsa yapılsın ciddi boyutta finansal sıkıntı yaşayan bir firma, bir yıl içerisinde ertelenen veya yeniden yapılandırılan kredi ödemelerini de yerine getiremeyecektir.

$\mathrm{Bu}$ nedenlerle bir firmanın finansal güçlük yaşadığının saptanmasıyla kredilerinin takip hesaplarına intikal etmesi arasında geçebilecek süre ortalama 1 yıl olarak kabul edilmiştir. Dolayısıyla, sektörel risk derecelendirmesi " $\mathrm{t}$ " yılı verileriyle yapıldıysa, kontrol verisi olarak sektörel takipteki krediler rasyolarına göre sıralama " $t+1$ ” yılı için hazırlanmış ve bu iki sektör sıralaması karşılaştırılmıştır. Burada amaç sektörel takipteki krediler rasyolarını öngörmek değil, yapılan sektörel risk derecelendirmesinin sağlıklı sonuçlar üretip üretmediğini kontrol etmektir. Sağlıklı sonuçlar elde edilmesi halinde, analizde kullanılan finansal rasyoların bir sonraki dönem için sektörlerin risklilik durumunu ortaya koyabilecek birer öncü gösterge olarak değerlendirilebilmesi de mümkün olacaktır.

Bankacılık faaliyetlerinde takip hesaplarına intikal eden sorunlu kredilerin yönetilmesi ve/veya bilançodan çıkartılmasına yönelik olarak geliştirilen birçok yöntem bulunmaktadır. Bunlardan en çok kullanılan yöntem, sorunlu kredilerin satılarak bilançodan çıkartılması esasına 
dayanmaktadır. $\mathrm{Bu}$ durumda bankalar takipteki krediler rasyolarını daha düşük düzeylere çekebilmektedir. Takipteki krediler rasyolarının rakamsal düzeyi bu çalışma için önem taşımadığından, uygulanan bu tip yöntemler analiz sonuçlarını etkilemeyecektir. Analiz sonuçlarının kontrolünün sağlanması için başvurulacak olan sektörel takipteki krediler rasyolarında, önemli olan bu rasyoların düzeyi değil, sektörlerin birbirlerine göre risklilik durumunun belirlenebilmesi ve böylece sıralanabilmesidir.

\subsection{Türkiye Sanayisi Finansal Rasyolarının 2013-2018 Dönemi Gelişimi}

Türkiye sanayisinin son beş yıllık finansal performansını değerlendirmek, bunun yanı sıra faktör analizinde kullanılacak finansal rasyoların tanıtılması amacıyla, Türkiye sanayisinin toplulaştırılmış mali tablolarından hareketle hesaplanmış olan 2013-2018 dönemine ait finansal rasyolar ve analizde kullanılan kodlar Tablo 1'de sunulmuştur. 
Tablo 1

Türkiye Sanayisine İlişkin Finansal Rasyolar (2013-2018)

\begin{tabular}{|c|c|c|c|c|c|c|c|}
\hline & & 2013 & 2014 & 2015 & 2016 & 2017 & 2018 \\
\hline & Likidite Rasyoları & & & & & & \\
\hline L1 & Cari Oran & 1,31 & 1,30 & 1,27 & 1,27 & 1,28 & 1,27 \\
\hline L2 & Asit Test Oran 1 & 0,85 & 0,83 & 0,81 & 0,81 & 0,82 & 0,80 \\
\hline L3 & Kisa Vadeli Alacaklar / Aktif Toplamı & 0,25 & 0,25 & 0,25 & 0,24 & 0,25 & 0,25 \\
\hline L4 & Kısa Vadeli Alacaklar / Dönen Varlıklar & 0,43 & 0,42 & 0,42 & 0,42 & 0,42 & 0,42 \\
\hline L5 & Nakit Oran1 & 0,23 & 0,21 & 0,20 & 0,20 & 0,20 & 0,19 \\
\hline L6 & Stok Bağımlılık Oranı & 2,00 & 2,02 & 2,07 & 2,08 & 2,06 & 2,06 \\
\hline L7 & Stoklar/Aktif Toplamı & 0,17 & 0,18 & 0,18 & 0,18 & 0,18 & 0,19 \\
\hline \multirow[t]{2}{*}{$\mathbf{L 8}$} & Stoklar/Dönen Varlıklar & 0,30 & 0,30 & 0,31 & 0,31 & 0,31 & 0,31 \\
\hline & Devir Hız Rasyoları & & & & & & \\
\hline D1 & Aktif Devir Hızı & 1,02 & 1,01 & 0,95 & 0,88 & 0,92 & 0,94 \\
\hline D2 & Alacak Devir Hızı & 5,19 & 5,12 & 4,74 & 4,46 & 4,55 & 4,64 \\
\hline D3 & Çalışma Sermayesi Devir Hızı & 1,75 & 1,73 & 1,64 & 1,52 & 1,56 & 1,59 \\
\hline D4 & Duran Varlıklar Devir Hızı & 2,44 & 2,41 & 2,25 & 2,08 & 2,25 & 2,32 \\
\hline D5 & Maddi Duran Varlıklar Devir Hızı & 4,75 & 4,64 & 4,33 & 4,08 & 4,42 & 4,57 \\
\hline D6 & Net Çalışma Sermayesi Devir Hızı & 7,35 & 7,46 & 7,66 & 7,17 & 7,10 & 7,48 \\
\hline D7 & Özkaynak Devir Hızı & 2,72 & 2,80 & 2,82 & 2,73 & 2,99 & 3,25 \\
\hline \multirow[t]{2}{*}{ D8 } & Stok Devir Hızı & 5,57 & 5,43 & 5,09 & 4,61 & 4,81 & 4,85 \\
\hline & Mali Yapı Rasyoları & & & & & & \\
\hline M1 & Banka Kredileri / Aktif Toplamı & 0,22 & 0,22 & 0,24 & 0,25 & 0,25 & 0,26 \\
\hline M2 & Banka Kredileri / Yabancı Kaynaklar Toplamı & 0,35 & 0,35 & 0,36 & 0,36 & 0,36 & 0,36 \\
\hline M3 & Kaldıraç Oranı & 0,63 & 0,64 & 0,66 & 0,68 & 0,69 & 0,71 \\
\hline M4 & Dönen Varlıklar / Aktif Toplamı & 0,58 & 0,58 & 0,58 & 0,58 & 0,59 & 0,59 \\
\hline M5 & Duran Varlıklar / Devamlı Sermaye & 0,75 & 0,76 & 0,77 & 0,78 & 0,76 & 0,76 \\
\hline M6 & Duran Varlıklar / Özkaynaklar & 1,12 & 1,16 & 1,25 & 1,31 & 1,33 & 1,40 \\
\hline M7 & Duran Varlıklar / Yabancı Kaynaklar Toplamı & 0,67 & 0,65 & 0,64 & 0,62 & 0,59 & 0,57 \\
\hline M8 & Kısa Vadeli Banka Kredileri / KV Yab. Kaynaklar & 0,21 & 0,21 & 0,21 & 0,20 & 0,19 & 0,19 \\
\hline M9 & Kısa Vadeli Yabancı Kaynaklar / Pasif Toplamı & 0,44 & 0,45 & 0,45 & 0,46 & 0,46 & 0,47 \\
\hline M10 & Kısa Vadeli Yabancı Kaynaklar / Yab. Kaynaklar & 0,71 & 0,70 & 0,69 & 0,67 & 0,67 & 0,66 \\
\hline M11 & Maddi Duran Varlıklar / Aktif Toplamı & 0,21 & 0,22 & 0,22 & 0,22 & 0,21 & 0,21 \\
\hline M12 & Maddi Duran Varlıklar / Özkaynaklar & 0,57 & 0,60 & 0,65 & 0,67 & 0,68 & 0,71 \\
\hline M13 & Maddi Duran Varlıklar / UV Yabancı Kaynaklar & 1,17 & 1,12 & 1,05 & 0,96 & 0,90 & 0,85 \\
\hline M14 & Özkaynaklar / Aktif Toplamı & 0,37 & 0,36 & 0,34 & 0,32 & 0,31 & 0,29 \\
\hline M15 & Özkaynaklar / Yabancı Kaynaklar & 0,60 & 0,56 & 0,51 & 0,47 & 0,44 & 0,41 \\
\hline M16 & Uzun Vadeli Yabanc1 Kaynaklar / Devamlı Sermaye & 0,33 & 0,35 & 0,38 & 0,41 & 0,43 & 0,46 \\
\hline M17 & Uzun Vadeli Yabancı Kaynaklar / Pasif Toplamı & 0,18 & 0,19 & 0,21 & 0,22 & 0,23 & 0,24 \\
\hline \multirow[t]{2}{*}{ M18 } & Ortaklara Borç / Aktif Toplamı & 0,06 & 0,07 & 0,07 & 0,08 & 0,08 & 0,08 \\
\hline & Kârlıık Rasyoları & & & & & & \\
\hline K1 & Brüt Satış Kârı / Net Satışlar & 0,13 & 0,12 & 0,13 & 0,13 & 0,13 & 0,14 \\
\hline $\mathbf{K} 2$ & Ekonomik Rantabilite & 0,05 & 0,05 & 0,05 & 0,04 & 0,06 & 0,06 \\
\hline K3 & Faaliyet Giderleri / Net Satışlar & 0,09 & 0,09 & 0,09 & 0,09 & 0,09 & 0,08 \\
\hline K4 & Faaliyet Kârı / Faaliyetin Gerçek. Kullanılan Varlık & 0,05 & 0,04 & 0,05 & 0,04 & 0,05 & 0,06 \\
\hline K5 & Faaliyet Kâr1 / Net Satışlar & 0,04 & 0,04 & 0,04 & 0,04 & 0,05 & 0,05 \\
\hline K6 & Faiz Giderleri / Net Satışlar & 0,02 & 0,02 & 0,03 & 0,03 & 0,03 & 0,05 \\
\hline $\mathbf{K} 7$ & Faiz Giderleri / Faiz ve Vergiden Önceki Kâr & 0,47 & 0,42 & 0,51 & 0,59 & 0,47 & 0,72 \\
\hline K8 & Net Kâr / Aktif Toplamı & 0,02 & 0,02 & 0,02 & 0,01 & 0,03 & 0,01 \\
\hline K9 & Net Kâr / Net Satışlar & 0,02 & 0,02 & 0,02 & 0,01 & 0,03 & 0,01 \\
\hline K10 & Net Kâr / Özkaynak & 0,05 & 0,06 & 0,06 & 0,04 & 0,08 & 0,04 \\
\hline K11 & Faiz Giderleri / (Net Kâr + Faiz Giderleri) & 0,55 & 0,48 & 0,57 & 0,68 & 0,52 & 0,81 \\
\hline K12 & Satılan Malın Maliyeti / Net Satışlar & 0,87 & 0,88 & 0,87 & 0,87 & 0,87 & 0,86 \\
\hline \multirow[t]{2}{*}{ K13 } & Vergi Öncesi Kâr / Özkaynak & 0,07 & 0,08 & 0,08 & 0,06 & 0,10 & 0,06 \\
\hline & Büyüme Rasyoları & & & & & & \\
\hline B1 & Aktif Artış1 (\%) & 0,22 & 0,16 & 0,20 & 0,16 & 0,19 & 0,21 \\
\hline B2 & Özkaynak Artışı (\%) & 0,12 & 0,12 & 0,12 & 0,11 & 0,13 & 0,15 \\
\hline B3 & Net Kâr Artışı (\%) & $-0,30$ & 0,40 & 0,08 & $-0,28$ & 1,47 & $-0,48$ \\
\hline B4 & Firma Sayısındaki Artış (\%) & 0,07 & 0,06 & 0,06 & 0,04 & 0,07 & 0,06 \\
\hline B5 & Brüt Satışlar Artışı (\%) & 0,15 & 0,16 & 0,13 & 0,08 & 0,24 & 0,24 \\
\hline B6 & Faaliyet Kârı Artış1 (\%) & 0,28 & 0,07 & 0,33 & 0,10 & 0,39 & 0,38 \\
\hline B7 & KV Yabancı Kaynaklardaki Artış (\%) & 0,24 & 0,17 & 0,22 & 0,16 & 0,20 & 0,23 \\
\hline B8 & UV Yabancı Kaynaklardaki Artış (\%) & 0,39 & 0,24 & 0,29 & 0,24 & 0,23 & 0,28 \\
\hline B9 & Mali Borçlardaki (kısa+uzun vadeli) Artış (\%) & 0,37 & 0,21 & 0,26 & 0,21 & 0,21 & 0,25 \\
\hline B10 & Ticari Borçlardaki (kısa+uzun vadeli) Artış (\%) & 0,23 & 0,16 & 0,25 & 0,13 & 0,22 & 0,21 \\
\hline B11 & Hazır Değerlerdeki Artış (\%) & 0,27 & 0,12 & 0,16 & 0,15 & 0,19 & 0,17 \\
\hline B12 & Ticari Alacaklardaki Artış (\%) & 0,22 & 0,17 & 0,21 & 0,15 & \begin{tabular}{|l|}
0,22 \\
\end{tabular} & 0,22 \\
\hline
\end{tabular}

Not. T.C. Sanayi ve Teknoloji Bakanlığı, Girişimci Bilgi Sistemi’nden alınmıştır. 
Türkiye sanayisinin son altı y1llık gelişimi değerlendirildiğinde, aktif kompozisyon yapısının değişmediği, pasif kompozisyonunda yabancı kaynaklar payının özkaynaklar aleyhine artış gösterdiği ve ağırlıklı olarak bu gelişmenin kaynağını "Uzun Vadeli Yabancı Kaynaklar"ın oluşturduğu saptanmıştır. Ayrıca 2016 yılında yaşanan Darbe Girişimi’nin olumsuz etkileri olarak, brüt satış artışında ve buna bağlı olarak aktif artışında yaşanan gerileme ile faiz giderlerindeki artışın rasyolara yansıdı̆̆ Tablo 1'den söylenebilir.

\subsection{Türk Bankacılık Sektörünün Sektörel Takipteki Krediler Rasyoları}

Türkiye Bankalar Birliği Risk Merkezi ile Sanayi ve Teknoloji Bakanlığı Girişim Bilgi Sistemi'nde yer alan sektörel ayrımların eşleştirdiği ve sektörlerin analizde kullanılan kısaltmaları Tablo 2'de sunulmuştur.

Tablo 2

Sektör Eşleştirme ve Kisaltmalar Tablosu

\begin{tabular}{|c|c|c|}
\hline $\begin{array}{l}\text { TÜRKIYYE BANKALAR BİRLİĞİ } \\
\text { RİSK MERKEZİ }\end{array}$ & $\begin{array}{l}\text { SANAYİ VE TEKNOLOJİ BAKANLIĞI } \\
\text { GİRIŞIMCİ BILGGI SİSTEMİ }\end{array}$ & \\
\hline Toptan, Perakende Tic., Komisync.Motorlu Araç Servis Hizm. & G - Toptan, Perakende Ticaret; Mot. Kara Taş. Ve Motosikletlerin Onarımı & toppertic \\
\hline İnşaat & $F$ - İnşaat & inşaat \\
\hline Elektrik Gaz Ve Su Kaynakları & D - Elektrik, Gaz, Buhar Ve İklimlendirme Üretimi Ve Dağtımı & elekgaz \\
\hline \multicolumn{3}{|l|}{ Taşımacilkk, Depolama Ve Haberleșme } \\
\hline Haberleșme & $\mathrm{J}$ - Bilgi Ve İletişim & bililet \\
\hline Taşımacılık & H - Ulaștırma Ve Depolama & ulaşdepo \\
\hline Diğer Tassımactlık Faaliyetleri Ve Depolama & H - Ulaştırma Ve Depolama & ulaşdepo \\
\hline Tarım, Avcilik, Ormancilik & A - Tarım, Ormancilık Ve Balıkçılık & tarorbal \\
\hline \multicolumn{3}{|l|}{ Tekstil Ve Tekstil Ürünleri San. } \\
\hline Tekstil Sanayii & 13 - Tekstil Ürünlerinin İmalat1 & tekstil \\
\hline Konfeksiyon Sanayii & 14 - Giyim Eşyalarının İmalatı & giyim \\
\hline Deri Giyim Ve Kürk Isleme San. & 15 - Deri Ve İlgili Ürünlerin İmalatı & deri \\
\hline Otel ve Restoranlar (Turizm) & I - Konaklama Ve Yiyecek Hizmeti Faaliyetleri & turizm \\
\hline \multicolumn{3}{|l|}{ Metal Ana San Ve İșlenmiş Mad. Ürt. } \\
\hline Metal Ana Sanayii & 24 - Ana Metal Sanayii & anametal \\
\hline Isslenmis Metal Ürünleri Sanayii (Makina Techizat Hariç) & 25 - Fabrikasyon Metal Ürünleri İmalatı (Makine Ve Teçhizat Hariç) & metalürün \\
\hline Gıda, Meşrubat Ve Tütün San. & $\begin{array}{l}10 \text { - Gıda Ürünlerinin İmalat1 } \\
11 \text { - İçeceklerin İmalatı } \\
12 \text { - Tütün Ürünleri İmalatı }\end{array}$ & $\begin{array}{l}\text { gida } \\
\text { içecek } \\
\text { tütün }\end{array}$ \\
\hline Finansal Aracilık & K - Finans Ve Sigorta Faaliyetleri & finsig \\
\hline Diğer Toplumsal Sosyal Ve Kișisel Hizmetler & R - Külttür, Sanat, Eğlence, Dinlence Ve Spor & külsan \\
\hline Kimya Ve Kimya Ürünleri İle Sent. Lif San. & $\begin{array}{l}20 \text { - Kimyasalların Ve Kimyasal Ürünlerin İmalatı } \\
21 \text { - Temel Eczacilk Ürünlerinin Ve Ecz. İliș. Malzemelerin İmalat1 }\end{array}$ & $\begin{array}{l}\text { kimya } \\
\text { eczacilik }\end{array}$ \\
\hline Diğer Metal Dıșı Madenler San. & 23 - Diğer Metalik Olmayan Mineral Ürünlerin İmalatı & mineral \\
\hline Kauçuk Ve Plastik Ür. San. & 22 - Kauçuk Ve Plastik Ürünlerin İmalatı & kauçukplastik \\
\hline \multicolumn{3}{|l|}{ Ulaşım Araçları San. } \\
\hline Motorlu Araçlar Ve Bunların Parça Ve Aksesuarları & 29 - Motorlu Kara Taşıtı, Treyler Ve Yarı Treyler İmalatı & motorluaraç \\
\hline Gemi Ve Teknelerin Yapımı Ve Tamiri Ile Diğ. Ulaşım Araç. Sanayii & 30 - Diğer Ulaşım Araçlarının İmalatı & diğerulaşım \\
\hline \multicolumn{3}{|l|}{ Makina Ve Teçhizat San. } \\
\hline Makina Ve Teçhizat & 28 - Başka Yerde Sinıflandırılmamış Makine Ve Ekipman İmalatı & diğermakine \\
\hline Elektrikli Ve Elektriksiz Ev Aletleri & 27 - Elektrikli Teçhizat İmalatı & elektrikliürün \\
\hline Elektrikli Ve Optik Aletler San. & 26 - Bilgisayarların, Elektronik Ve Optik Ürünlerin İmalat1 & elektronik \\
\hline Sağllk Ve Sosyal Hizmetler & Q - İnsan Sağlığı Ve Sosyal Hizmet Faaliyetleri & sağlik \\
\hline \multicolumn{3}{|l|}{ Kağtt Ham. Ve Kağıt Ürnl. Basım San. } \\
\hline Kağt Ham. Ve Kağt Ürnl. Imalatı & 17 - Kağıt Ve Kağtt Ürünlerinin İmalatı & kağıt \\
\hline Basım Sanayii & 18 - Kayıtlı Medyanın Basılması Ve Çoğaltılması & basim \\
\hline Başka Yerlerde Sınıflandırılmamıș İmalat Sanayii & 32 - Diğer İmalatlar & diğerimalat \\
\hline Enerji Üreten Madenlerin Çıkarılması & B - Madencilik Ve Taş Ocakçıllı̆ı & madocak \\
\hline Enerji Üretmeyen Madenlerin Çkarılması & B - Madencilik Ve Tas Ocakçllı̆g & madocak \\
\hline Eğitim & $P$ - Eğitim & eğitim \\
\hline Ağaç Ve Ağaç Ürünleri Sanayi & $\begin{array}{l}16 \text { - Ağaç, Ağaç Ürünleri Ve Mantar Ürünleri İmalatı (Mobilya Hariç) } \\
31 \text { - Mobilya İmalatı }\end{array}$ & $\begin{array}{l}\text { ağaç } \\
\text { mobilya }\end{array}$ \\
\hline Deri Ve Deri Ürünleri Sanayi & 15 - Deri Ve İlgili Ürünlerin İmalatı & deri \\
\hline Balıçlık & A - Tarım, Ormancilık Ve Balıkçllk & tarorbal \\
\hline
\end{tabular}


Sektörel risk derecelendirmesinin kontrol seti olarak hazırlanan, 2016-2019 dönemine ilişkin yıllık takipteki krediler rasyolarına göre sıralanmış sektörlere Tablo 3'te yer verilmiştir.

Tablo 3

Sektörlerin Takipteki Krediler Rasyosuna Göre Sıralaması

\begin{tabular}{|c|c|c|c|c|c|c|c|}
\hline \multicolumn{2}{|l|}{2016} & \multicolumn{2}{|l|}{2017} & \multicolumn{2}{|l|}{2018} & \multicolumn{2}{|l|}{2019} \\
\hline Sektör & $\begin{array}{l}\text { Takipteki } \\
\text { Krediler } \\
\text { Rasyosu }\end{array}$ & Sektör & $\begin{array}{c}\text { Takipteki } \\
\text { Krediler } \\
\text { Rasyosu }\end{array}$ & Sektör & $\begin{array}{c}\text { Takipteki } \\
\text { Krediler } \\
\text { Rasyosu }\end{array}$ & Sektör & $\begin{array}{l}\text { Takipteki } \\
\text { Krediler } \\
\text { Rasyosu }\end{array}$ \\
\hline finsig & 0,53 & finsig & 0,34 & finsig & 0,48 & finsig & 0,43 \\
\hline elekgaz & 0,92 & elekgaz & 0,70 & motorluaraç & 1,16 & bililet & 1,97 \\
\hline bililet & 0,93 & bililet & 0,94 & bililet & 1,69 & kağıt & 2,13 \\
\hline motorluaraç & 1,25 & motorluaraç & 1,17 & kimya/eczacilik & 1,92 & kimya/eczacilik & 2,22 \\
\hline kimya/eczacilık & 1,70 & kimya/eczacılık & 1,65 & kağıt & 2,00 & motorluaraç & 2,32 \\
\hline ulaşdepo & 1,98 & kağgt & 1,86 & basim & 2,02 & basim & 2,38 \\
\hline kağıt & 2,30 & ulaşdepo & 2,02 & ulaşdepo & 2,33 & ulaşdepo & 3,15 \\
\hline sağl1k & 2,56 & külsan & 2,27 & elektrikliürün & 2,78 & anametal & 3,85 \\
\hline tarorbal & 2,73 & sağlık & 2,27 & ağaç/mobilya & 2,99 & sağlık & 4,34 \\
\hline metalürün & 2,91 & tarorbal & 2,64 & elekgaz & 3,39 & külsan & 4,34 \\
\hline külsan & 3,08 & ağaçmobilya & 2,69 & diğermakine & 3,44 & diğermakine & 4,80 \\
\hline anametal & 3,18 & elektrikliürün & 2,79 & külsan & 3,51 & mineral & 4,91 \\
\hline gida & 3,24 & metalürün & 2,93 & anametal & 3,68 & elektrikliürün & 4,91 \\
\hline turizm & 3,39 & diğermakine & 2,95 & elektronik & 3,78 & metalürün & 5,06 \\
\hline elektrikliürün & 3,40 & kauçukplastik & 3,13 & giyim/deri/tekstil & 3,99 & ağaç/mobilya & 5,58 \\
\hline kauçukplastik & 3,45 & gida içecektütün & 3,31 & sağlık & 4,00 & elekgaz & 6,50 \\
\hline ağaç/mobilya & 3,53 & inşaat & 3,64 & tarorbal & 4,09 & gida & 6,61 \\
\hline diğermakine & 3,73 & anametal & 3,77 & metalürün & 4,11 & giyim/deri/tekstil & 6,90 \\
\hline giyim/deri/tekstil & 3,93 & basim & 3,88 & mineral & 4,69 & madocak & 7,18 \\
\hline inşaat & 3,97 & elektronik & 3,90 & eğitim & 4,97 & diğerulaşım & 7,23 \\
\hline basim & 4,00 & turizm & 3,91 & inşaat & 4,97 & tarorbal & 7,43 \\
\hline madocak & 4,19 & giyim/deri/tekstil & 4,25 & turizm & 5,29 & diğerimalat & 8,25 \\
\hline diğerimalat & 4,27 & eğitim & 4,29 & gida & 5,58 & toppertic & 8,26 \\
\hline elektronik & 4,42 & madocak & 4,35 & kauçukplastik & 5,58 & turizm & 8,96 \\
\hline toppertic & 4,61 & toppertic & 4,44 & madocak & 5,80 & kauçukplastik & 9,87 \\
\hline eğitim & 4,67 & mineral & 4,57 & toppertic & 5,89 & elektronik & 10,24 \\
\hline mineral & 6,07 & diğgerimalat & 4,85 & diğerimalat & 6,18 & inşaat & 10,84 \\
\hline diğerulaşım & 11,52 & diğerulaşım & 11,22 & diğerulaşım & 7,36 & eğitim & 11,45 \\
\hline
\end{tabular}

Not. Türkiye Bankalar Birliği, Risk Merkezi'nden alınmıştır.

Risk Merkezi verileri kullanılarak hazırlanan Tablo 3'te, sonraki bölümde mali tabloların alındığı Sanayi ve Teknoloji Bakanlığı'nın veri tabanındaki sektörel ayrımla eşlenemeyen veya gizlilik esasına bağlı olarak finansal rasyolarının tamamı hesaplanamayan sektörlere yer verilmemiştir. Bunlar; Savunma ve Kamu Yönetimi, Zorunlu Sosyal Güvenlik Kurumları, Nükleer Yakıt Rafineri ve Petrol-Kömür Ürünleri ile Emlak Komisyon, Kiralama ve İşletmecilik Faaliyetleri sektörleridir. 
Tablo 3'te en düşük takipteki krediler rasyosundan yükseğe doğru sektörler sıralanmış ve buna göre en düşük takip rasyosuna sahip sektör en iyi performans gösteren sektör olarak değerlendirilmiştir. 2016-2019 döneminde en düşük takip rasyosuna sahip olan, dolayısıyla en iyi performans gösteren sektör "Finansal Aracılık" iken, 2016-2018 döneminde en yüksek takip rasyosuna sahip sektör "Diğer Ulaşım Araçları Sanayi”, 2019 yılında ise "Eğitim” sektörü olmuştur. Ayrıca 2017 yılı sonrasında "Elektrik, Gaz ve Su Kaynakları” ve "İnşaat” sektörlerinin sürekli artan takipteki krediler rasyolarına bağlı olarak sıralamada aşağıya doğru kaymaları dikkat çekmektedir.

\section{Sektörel Risk Derecelendirmesi}

Sektörlerin yılsonu mali tabloları üzerinden hesaplanan finansal rasyolar kullanılarak faktör analizi yöntemiyle sektörel risk derecelendirmesi yapılmıştır. Sektörel risk derecelendirmesi ile sektörel takipteki krediler rasyolarına göre yapılan sıralama karşılaştırılarak sonuçlarının tutarlılı̆̆ını değerlendirilmiştir.

\subsection{Faktör Analizi Yöntemi}

Faktör analizi, birbiriyle ilişkili çok sayıda değişkeni bir araya getirerek daha az sayıda kavramsal olarak anlamlı ve birbirinden ilişkisiz yeni değişkenler üretmeyi amaçlayan çok değişkenli bir istatistik yöntemdir. Faktör Analizi bir yandan değişkenlere keyfi ağırlık vermek zorunluluğundan kurtararak önemli bir kolaylık sağlarken, diğer yandan çok sayıda değişkenden, bu değişkenlerin kapsadığı bilginin büyük bir kısmını taşıyan az sayıda varsayımsal değişkenin elde edilmesini mümkün kılmaktadır (Tatlıdil, 2002).

Finansal rasyolar mali durum hakkında önemli ipuçları içermesine rağmen, karar birimleri tarafından birçok halde karar vermeye yardımcı olacak az sayıda göstergeye gereksinim vardır. Çok sayıda değişkenin birlikte değerlendirilmesinde karşılaşılan en önemli sorun ise; değişkenler arasındaki güçlü ilişkilerden kaynaklanmaktadır. Çok değişkenli istatistik, inceleme konusu olayı bir bütün olarak ele almakta ve bütünlüğü sağlayan değişkenlerin bağımlılık yapısını açıklamaya çalışmaktadır. Diğer yandan da birden çok özelliğin analiziyle ilgilendiğinden uygulamalarda; basitleştirme ve boyut indirgeme, birimlerin sınıflandırılması, gibi değişik amaçlara da hizmet etmektedir (Tosuner, vd., 2002). 
Bu çalışmada "Faktör Analizi" yönteminin tercih edilmesinde etkili olan neden, analiz sonucunda hesaplanan faktör skorlarının varyansı açıklama gücüyle ağırlıklandırmak suretiyle toplanmasıyla, her sektör için elde edilen genel faktörün, sektörlerin aynı ölçü birimiyle karşılaştırılmalarını dolayısıyla risk derecelendirmesini mümkün kılmasıdır. Aynı zamanda faktör analizi yönteminin yatay kesit bir analiz olması, diğer bir deyişle tek bir döneme ilişkin sistem analizine olanak tanıması, çalışmaya konu olan sanayi sektörünün o döneme ilişkin makroekonomik gelişmelerden ne yönde etkilendiğini de saptamak açısından büyük önem taşımaktadır.

\subsection{Faktör Analizi Uygulaması}

Sektörel risk derecelendirmesi 2015-2018 dönemi için uygulanmış, analizde 31.12.2015, 31.12.2016, 31.12.2017 ve 31.12.2018 sektörel mali tablolarından hareketle hesaplanan finansal rasyolardan oluşan dört farklı veri seti kullanılmıştır.

Sanayi ve Teknoloji Bakanlığı Girişimci Bilgi Sistemi’nden 2015-2019 dönemi yılsonuna ait 17 genel sektör ve 24 imalat alt sanayi sektörü olmak üzere toplam 41 sektöre ilişkin bilanço ve gelir tablosu alınmıştır. Genel sektörlerden "Diğerleri” sınıflandırılamayan sektörlerin toplulaştırılmasıyla oluşturulduğundan, imalat sanayi alt sektörlerinden "Kok Kömürü ve Rafine Edilmiş Petrol Ürünleri İmalatı” ise gizlilik kısıtları nedeniyle açıklanmayan verilerine bağlı olarak analiz dışında bırakılmıştır.

Mali tablolardan hareketle "Likidite Rasyoları", "Devir H1zı Rasyoları”, "Mali Yap1 Rasyoları", "Kârlılık Rasyoları" ve "Büyüme Rasyoları” olmak üzere beş başlıkta toplanabilecek 59 finansal rasyo hesaplanmış ve finansal rasyolar listesi Tablo 1'de verilmişti. Analizde finansal rasyo kullanılması, büyüklük itibariyle homojen olmayan sektörel mali tablolardan, homojen bir veri seti elde edilebilmesini sağlamıştır. Ayrıca sektörler arasında önemli farklılaşmalara neden olabilecek, özellikle stoklar ve maddi duran varlıklar gibi sektörün üretim ve yatırım kapsamına göre değişkenlik gösteren finansal rasyolar, analiz dışında bırakılmıştır.

2015-2018 döneminde her yıl için ayrı ayrı yapılan faktör analizi uygulamasının geçerlilik testi sonuçlarına Tablo 4'te yer verilmiştir. 
Tablo 4

Kaiser-Meyer-Olkin (KMO) ve Bartlett Küresellik Testi

\begin{tabular}{|c|c|c|c|c|c|}
\hline \multirow{2}{*}{\multicolumn{2}{|c|}{ geklem Ölcüm Yeterliliŏi }} & 2015 & 2016 & 2017 & 2018 \\
\hline & & 0,585 & 0,635 & 0,637 & 0,649 \\
\hline \multirow{3}{*}{ Bartlett Küresellik Testi } & Ki-Kare & 758,72 & 783,25 & 748,30 & 719,47 \\
\hline & Serbestlik Derecesi & 120 & 153 & 153 & 120 \\
\hline & Olasilik & 0,00 & 0,00 & 0,00 & 0,00 \\
\hline
\end{tabular}

KMO değeri veri setinin faktör analizine uygun olup olmadığını gösteren bir ölçüt olup bir test istatistiği değildir. Veriler arasındaki korelasyon katsayılarından hareketle hesaplanan KMO değeri için, genel olarak uygulamalarda 0,50 değerinin alt sınır olması gerektiği ve altındaki değerler için veri setine faktör analizi uygulanamayacağı kabul edilmektedir. Tablo 4 'te verilen KMO değerleri, dört yıl için de veri setinin faktör analizine uygun olduğuna işaret etmektedir. Barlett küresellik testi sonucunda ise, Ki-Kare değerine ilişkin olasılığın çok küçük bir değer alması, "değiş̧kenler arasında ilişki yoktur" hipotezinin reddedilmesini sağlamakta ve korelasyon matrisinin anlamlı olduğunu göstermektedir.

2015-2018 yıllarına ilişkin yapılan analizler sonucunda elde edilen özdeğerler ve faktörlerin varyans açıklama yüzdeleri Tablo 5'te sunulmuştur.

Tablo 5

Faktörlerin Özdeğerleri ve Varyans Açıklama Yüzdeleri

\begin{tabular}{|c|c|c|c|c|c|c|c|c|c|c|c|c|}
\hline \multirow[b]{2}{*}{ Faktör } & \multicolumn{3}{|c|}{2015} & \multicolumn{3}{|c|}{2016} & \multicolumn{3}{|c|}{2017} & \multicolumn{3}{|c|}{2018} \\
\hline & Özdeğer & \begin{tabular}{|c|} 
Tekil \\
Varyans \\
Açıklama \\
$(\%)$ \\
\end{tabular} & $\begin{array}{c}\text { Kümülatif } \\
\text { Varyans } \\
\text { Açıklama } \\
(\%) \\
\end{array}$ & Özdeğer & $\begin{array}{c}\text { Tekil } \\
\text { Varyans } \\
\text { Açıklama } \\
(\%) \\
\end{array}$ & $\begin{array}{c}\text { Kümülatif } \\
\text { Varyans } \\
\text { Açıklama } \\
(\%) \\
\end{array}$ & Özdeğer & \begin{tabular}{|c|} 
Tekil \\
Varyans \\
Açıklama \\
$(\%)$ \\
\end{tabular} & $\begin{array}{c}\text { Kümülatif } \\
\text { Varyans } \\
\text { Açı klama } \\
(\%) \\
\end{array}$ & Özdeğer & \begin{tabular}{|c|} 
Tekil \\
Varyans \\
Açıklama \\
$(\%)$ \\
\end{tabular} & \begin{tabular}{|c|} 
Kümülatif \\
Varyans \\
Açıklama \\
$(\%)$ \\
\end{tabular} \\
\hline 1 & 4,73 & 29,56 & 29,56 & 5,98 & 33,25 & 33,25 & 6,29 & 34,93 & 34,93 & 6,43 & 40,18 & 40,18 \\
\hline 2 & 4,06 & 25,40 & 54,96 & 4,14 & 23,01 & 56,26 & 4,15 & 23,07 & 58,00 & 3,87 & 24,19 & 64,37 \\
\hline 3 & 2,83 & 17,69 & 72,65 & 3,25 & 18,05 & 74,30 & 2,51 & 13,95 & 71,95 & 2,17 & 13,56 & 77,93 \\
\hline 4 & 2,07 & 12,93 & 85,58 & 1,74 & 9,68 & 83,98 & 1,52 & 8,45 & 80,40 & 1,05 & 6,58 & 84,51 \\
\hline 5 & 0,75 & 4,68 & 90,26 & 0,66 & 3,67 & 87,65 & 1,11 & 6,18 & 86,58 & 0,68 & 4,26 & 88,77 \\
\hline 6 & 0,63 & 3,93 & 94,19 & 0,63 & 3,48 & 91,13 & 0,61 & 3,37 & 89,95 & 0,59 & 3,67 & 92,44 \\
\hline 7 & 0,31 & 1,97 & 96,16 & 0,51 & 2,82 & 93,95 & 0,48 & 2,68 & 92,63 & 0,44 & 2,76 & 95,20 \\
\hline 8 & 0,20 & 1,24 & 97,40 & 0,37 & 2,04 & 95,99 & 0,39 & 2,18 & 94,81 & 0,22 & 1,38 & 96,58 \\
\hline 9 & 0,15 & 0,97 & 98,37 & 0,20 & 1,14 & 97,13 & 0,27 & 1,52 & 96,33 & 0,20 & 1,27 & 97,85 \\
\hline 10 & 0,13 & 0,80 & 99,17 & 0,17 & 0,95 & 98,08 & 0,22 & 1,22 & 97,55 & 0,13 & 0,81 & 98,66 \\
\hline 11 & 0,07 & 0,42 & 99,59 & 0,11 & 0,61 & 98,69 & 0,13 & 0,75 & 98,30 & 0,07 & 0,45 & 99,12 \\
\hline 12 & 0,03 & 0,19 & 99,78 & 0,07 & 0,42 & 99,11 & 0,10 & 0,58 & 98,88 & 0,07 & 0,43 & 99,55 \\
\hline 13 & 0,02 & 0,12 & 99,90 & 0,06 & 0,35 & 99,46 & 0,09 & 0,53 & 99,40 & 0,04 & 0,26 & 99,80 \\
\hline 14 & 0,01 & 0,06 & 99,96 & 0,05 & 0,27 & 99,73 & 0,06 & 0,34 & 99,74 & 0,03 & 0,16 & 99,96 \\
\hline 15 & 0,00 & 0,03 & 99,99 & 0,02 & 0,13 & 99,86 & 0,03 & 0,14 & 99,88 & 0,00 & 0,02 & 99,99 \\
\hline 16 & 0,00 & 0,01 & 100,00 & 0,02 & 0,10 & 99,96 & 0,01 & 0,07 & 99,96 & 0,00 & 0,01 & 100,00 \\
\hline 17 & & & & 0,01 & 0,04 & 99,99 & 0,01 & 0,04 & 100,00 & & & \\
\hline 18 & & & & 0,00 & 0,01 & 100,00 & 0,00 & 0,00 & 100,00 & & & \\
\hline
\end{tabular}


2015 ve 2018 analizinde 16 finansal rasyo, 2016 ve 2017 analizinde ise 18 finansal rasyo kullanıldığından, finansal rasyo sayısı kadar faktör elde edilmiştir. Kaiser ölçütü özdeğeri 1'den büyük olan faktör sayısını temel aldığından, 2015, 2016 ve 2018 yıllarında 4 faktör, 2017 yılında ise 5 faktör belirlenmiştir. Böylece faktör analizi yardımıyla 2015 ve 2018 yıllarında 16 finansal rasyodan 4 faktöre, 2016 yılında 18 finansal rasyodan 4 faktöre, 2017 yılında da 18 finansal rasyodan 5 faktöre boyut indirgeme işlemi yapılmıştır. 2015 yılı analizinde ilk faktör varyansın \%29,56'sını açıklama gücüne sahip iken, toplam 4 faktörün varyansı açıklama gücü \%85,58 düzeyindedir. 2017 yılında \%86,58'le en yüksek varyans açıklama gücüne ulaşılmış, 2018 yılında ise ilk faktörün açıklama gücü \%40,18 düzeyine kadar yükselmiştir.

2015-2018 analiz döneminde elde edilen faktörde yoğunlaşan finansal rasyoların saptandığı faktör yapı matrislerine Tablo 6'da yer verilmiştir.

Tablo 6

Faktör Yapı Matrisleri
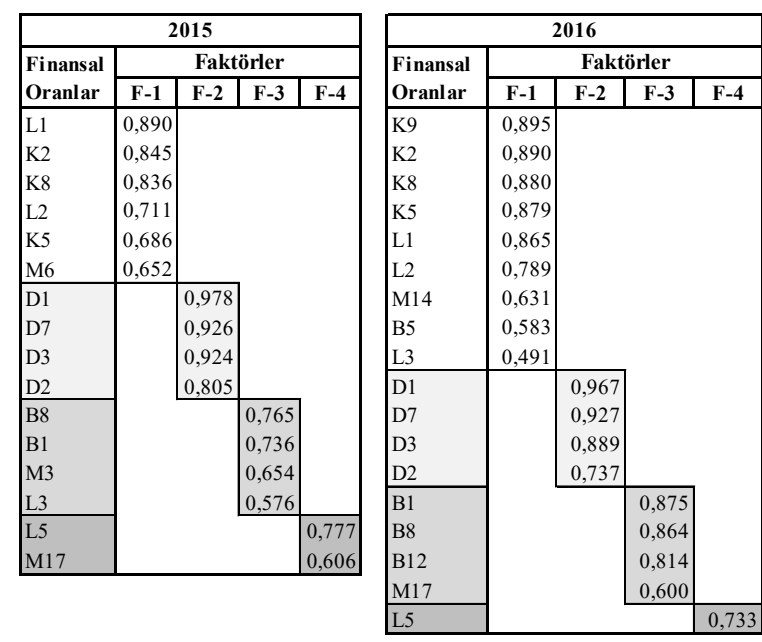

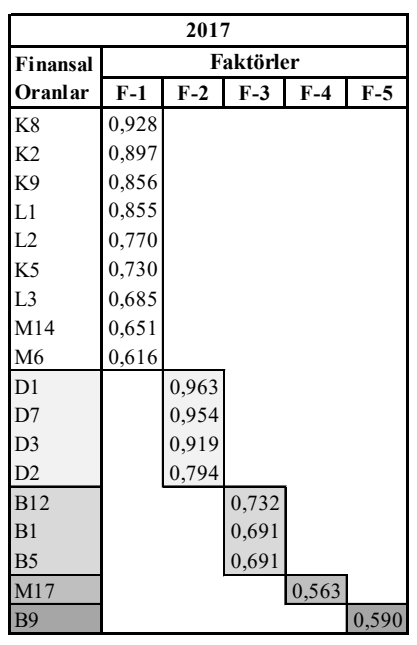

Finansal rasyolarla faktörler arasındaki ilişkileri ortaya koyan faktör yapı matrislerinde, finansal rasyolar en yüksek ilişkide olduğu faktör içerisinde sınıflandırılmaktadır. Yalnızca 2018 yılında özdeğeri 1'den büyük olmasına rağmen dördüncü faktörde belirgin olarak yoğunlaşmış bir finansal rasyo bulunmadığından, finansal rasyolardan ilişkisi ikincil olarak en yüksek olan rasyolar dördüncü faktörde gösterilmiştir. Finansal rasyoların faktörler içerisindeki sınıflandırmasını belirginleştirmek amacıyla her faktöre ilişkin farklı bir renk tonu kullanılmıştır. Faktörlerde yoğunlaşan finansal rasyoların açık tanımları Tablo 7'de verilmiştir. 
Tablo 7

Faktörlerde Yoğunlaşan Finansal Rasyolar

\begin{tabular}{|c|c|c|c|c|c|c|c|}
\hline \multicolumn{2}{|r|}{2015} & \multicolumn{2}{|r|}{2016} & \multicolumn{2}{|r|}{2017} & \multicolumn{2}{|r|}{2018} \\
\hline L1 & Cari Oran & K9 & Net Kâr / Net Satışlar Oranı & K8 & Net Kâr / Aktif Toplamı & K8 & Net Kâr / Aktif Toplamı \\
\hline K2 & Ekonomik Rantabilite & K2 & Ekonomik Rantabilite & K2 & Ekonomik Rantabilite & L1 & Cari Oran \\
\hline K8 & Net Kâr / Aktif Toplamı & K8 & Net Kâr / Aktif Toplamı & K9 & Net Kâr / Net Satışlar Oranı & K9 & Net Kâr / Net Satışlar Oranı \\
\hline L2 & Asit Test Oranı & K5 & Faaliyet Kârı / Net Satışlar & L1 & Cari Oran & B2 & Özkaynak Artış1 (\%) \\
\hline K5 & Faaliyet Kâr1 / Net Satışlar & L1 & Cari Oran & L2 & Asit Test Oranı & K2 & Ekonomik Rantabilite \\
\hline M6 & Özkaynaklar / Duran Varlıklar & L2 & Asit Test Oran1 & K5 & Faaliyet Kârı / Net Satışlar & L3 & Kısa Vadeli Alacaklar/Aktif Toplamı \\
\hline D1 & Aktif Devir Hızı & M14 & Özkaynaklar / Aktif Toplamı & L3 & Kısa Vadeli Alacaklar/Aktif Toplamı & L2 & Asit Test Oranı \\
\hline D7 & Özkaynak Devir Hızı & B5 & Brüt Satışlar Artışı (\%) & M14 & Özkaynaklar / Aktif Toplamı & M6 & Özkaynaklar / Duran Varlıklar \\
\hline D3 & Çalışma Sermayesi Devir Hızı & L3 & Kisa Vadeli Alacaklar/Aktif Toplamı & M6 & Özkaynaklar / Duran Varlıklar & M14 & Özkaynaklar / Aktif Toplamı \\
\hline D2 & Alacak Devir Hızı & D1 & Aktif Devir Hızı & D1 & Aktif Devir Hızı & D1 & Aktif Devir Hızı \\
\hline B8 & Uzun Vadeli Yab.Kay.daki Artıs (\%) & D7 & Özkaynak Devir Hızı & D7 & Özkaynak Devir Hızı & D7 & Özkaynak Devir Hızı \\
\hline B1 & Aktif Artışı (\%) & D3 & Çalışma Sermayesi Devir Hızı & D3 & Çalışma Sermayesi Devir Hızı & D3 & Çalışma Sermayesi Devir Hızı \\
\hline M3 & Kaldıraç Oranı & D2 & Alacak Devir Hızı & D2 & Alacak Devir Hızı & D2 & Alacak Devir Hızı \\
\hline $\mathbf{L 3}$ & Kısa Vadeli Alacaklar/Aktif Toplamı & B1 & Aktif Artış1 (\%) & B12 & Ticari Alacaklardaki Artış (\%) & B9 & Mali Borçlardaki Artış (\%) \\
\hline L5 & Nakit Oranı & B8 & Uzun Vadeli Yab.Kay.daki Artış (\%) & B1 & Aktif Artış1 (\%) & B1 & Aktif Artış1 (\%) \\
\hline M17 & Uzun Vadeli Yab.Kay./Pasif Toplamı & B12 & Ticari Alacaklardaki Artış (\%) & B5 & Brüt Satışlar Artış1 (\%) & M17 & Uzun Vadeli Yab.Kay./Pasif Toplamı \\
\hline & & M17 & Uzun Vadeli Yab.Kay. / Pasif Toplam & M17 & Uzun Vadeli Yab.Kay./Pasif Toplamı & & \\
\hline & & $\mathbf{L 5}$ & Nakit Oranı & B9 & Mali Borçlardaki Artış (\%) & & \\
\hline
\end{tabular}

Finansal rasyoların yoğunlaştığı faktörlerin takibini kolaylaştırmak amacıyla Tablo 6'da kullanılan renk tonları Tablo 7'de de kullanılmıştır. Birinci faktörün en yüksek tekil varyans açıklama gücüne sahip olduğu ve takip eden faktörlerin tekil varyans açıklama güçlerinin giderek azaldığı Tablo 5'te gösterilmişti. Dolayısıyla Tablo 7'de renk tonlarının koyulaşmasıyla, ilgili faktörün ve aynı zamanda bu faktörde yoğunlaşan finansal rasyoların varyansı açıklama güçlerinin azaldığına vurgu yapılmıştır.

2015-2018 dönemi analizlerinde faktör yapı matrislerinde yoğunlaşan finansal rasyolar çok değişmediğinden, genel olarak birinci faktörü "kârlılık-likidite-mali yapı", ikinci faktörü "devir hızı”, üçüncü faktörü de “büyüme” olarak adlandırmak mümkün görünmektedir. 2016 y1lında çalışmanın önceki bölümlerinde belirlenmiş olan Darbe Girişimi'nin mali tablolara olumsuz etkilerinin analiz sonuçlarına da yansıdığı gözlenmiştir. Bu etki şu şekilde açıklanabilir: 2016 yılında analiz kapsamındaki diğer üç yıldan farklı olarak, brüt satışlar artışı (B5) rasyosunun varyans açıklama gücü diğer yıllara göre önemli oranda artmış ve analiz döneminde ilk defa brüt satışlar artışı rasyosu birinci faktörde yoğunlaşmıştır. 2016 yılındaki ekonomik büyüme oranı yavaşlamasının, Türkiye sanayisine ait toplulaştırılmış mali tablolarına brüt satışlarda ve aktif büyümesinde azalma şeklinde yansıdığı saptanmıştı. Dolayısıyla 2016 yılı özelinde yaşanan bu gelişmenin analiz sonucuna da yansıması, analizin makroekonomik gelişmelere karşı da duyarlı olduğunu göstermektedir. 
Özetle, 2015 yılı analizinde, yüksek yabancı kaynakla (borçlanma) çalışan likidite ve kârlılık düzeyi yüksek olan sektörler, iyi performans gösteren sektörler olarak belirlenmiştir. 2016 yılındaki Darbe Girişimi’ne bağlı olumsuz gelişmeler, yalnızca bu yıl özelinde brüt satışlardaki artış rasyosunun sektör performansları üzerindeki önemini arttırmıştır. 2017 yılı analizinde ise yabancı kaynak (borçlanma) yerine özkaynaklarıyla faaliyetlerini sürdüren, yüksek kârlılık ve likidite ile birlikte faaliyetlerini artıran sektörler, iyi performans gösteren sektörler olarak sıralandırılmıştır. Türk bankacılık sektörü reel kredi artış oranları 2015 yılından sonra düşmeye başladığından, bunun yansıması olarak da faktör analizi sonuçlarında 2015 yılında ön plâna çıkan yabancı kaynaklara ilişkin finansal rasyoların yerini özkaynak rasyosu almıştır. 2018 yılında ise özkaynak artışının da birinci faktöre girmesiyle özkaynak düzeyi firmalar için kritik öneme sahip olmuştur. Yine yüksek kârlılık ve likidite iyi performansın bir göstergesi olarak devam etmiş, bunun yanı sıra kısa ve uzun vadeli mali borçlardaki artış diğer bir ifadeyle bankalarca sınırlı arzı sağlanan kredileri kullanabilen sektörlerin performansı pozitif yönde etkilenmeye başlamıştır.

Son dört yılın analiz sonuçlarında varyansı açıklama gücü en yüksek olan birinci faktörde yoğunlaşmış finansal rasyolara Tablo 8'de yer verilmiştir.

Tablo 8

En Yüksek Açıklama Gücüne Sahip Finansal Rasyolar (2015-2018)

\begin{tabular}{|l|c|c|c|c|}
\hline L1: Cari Oran & 2015 & 2016 & 2017 & 2018 \\
\hline L2: Asit Test Oranı & 2015 & 2016 & 2017 & 2018 \\
\hline L3: Kısa Vadeli Alacaklar/Aktif Toplamı & & 2016 & 2017 & 2018 \\
\hline K2: Ekonomik Rantabilite & 2015 & 2016 & 2017 & 2018 \\
\hline K5: Faaliyet Kâr/Net Satışlar & 2015 & 2016 & 2017 & \\
\hline K8: Net Kâr/Aktif Toplamı & 2015 & 2016 & 2017 & 2018 \\
\hline K9: Net Kâr/Net Satışlar & & 2016 & 2017 & 2018 \\
\hline M6: Özkaynaklar/Duran Varlıklar & 2015 & & 2017 & 2018 \\
\hline M14: Özkaynaklar/Aktif Toplamı & & 2016 & 2017 & 2018 \\
\hline B2: Özkaynak Artış1 (\%) & & & & 2018 \\
\hline B5: Brüt Satışar Artış1 (\%) & & 2016 & & \\
\hline
\end{tabular}

Tablo 8'de ilgili yılın analizinde birinci faktörde yoğunlaşan yüksek açıklama gücüne sahip rasyolar koyu renkle işaretlenmiştir. Her dört yılda koyu renkle işaretlenmiş ortak rasyolar; L1, L2, K2 ve K8'dir. Diğer yıllardan farklı olarak, 2016 yılında brüt satış artışının, 2018 yılında da özkaynak artışının açıklama gücünde büyük artış yaşandığı ve böylece birinci faktörde yoğunlaştığı 


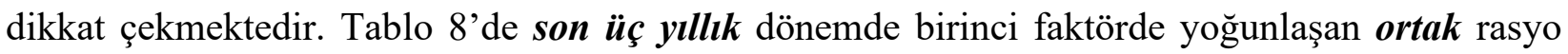
sayısının arttığı gözlenmektedir. Bu rasyolardan son üç yılda da süreklilik gösteren;

- Cari Oran (L1: Dönen Varlıklar/Kısa Vadeli Yabancı Kaynaklar)

- $\quad$ Asit Test Oranı (L2: Dönen Varlıklar-(Stoklar+Gelecek Aylara Ait Giderler+Diğer Dönen Varlıklar)/Kisa Vadeli Yabancı Kaynaklar)

- Kisa Vadeli Alacaklar/Aktif Toplamı (L3)

- Ekonomik Rantabilite (K2: (Vergi Öncesi Kâr+Finansman Giderleri)/Pasif Toplamı)

- $\quad$ Net Kâr / Aktif Toplamı (K8)

- $\quad$ Net Kâr / Net Satışlar Oranı (K9)

- Özkaynaklar/Aktif Toplamı (M14)

rasyolarının sektörel farklılaşmayı ortaya koyan en önemli göstergeler olarak değerlendirilmesi mümkündür.

2015-2018 dönemi yıllık analizlerinde elde edilen faktör skorlarının, varyansı açıklama gücüyle ağırlıklandırılarak toplanmasıyla ağırlıklı aritmetik ortalama alınmış ve böylece her sektör için genel faktör skoru elde edilmiştir. Aritmetik ortalama, duyarlılığı en yüksek ortalamadır ve herhangi bir birim değerinde olacak çok küçük bir değişim aritmetik ortalamayı etkilemektedir (Kılıçkaplan, 2019). Bu noktadan hareketle genel faktör skorunun hesaplanmasına yönelik kullanılan formül aşağıda verilmiştir.

$$
\mathrm{GFS}_{\mathrm{i}}=\sum_{\mathrm{j}=1}^{\mathrm{m}} \mathrm{FS}_{\mathrm{ij}} \times \mathrm{VAG}_{\mathrm{j}} / \sum_{\mathrm{j}=1}^{\mathrm{m}} \mathrm{VAG}_{\mathrm{j}}
$$

i: $1,2, \ldots, n$ (Sektör Sayısı); j=1, 2, .., m (Faktör Sayısı)

$G S_{i}$ : i. Sektör Genel Faktör Skoru

$F_{\mathrm{ij}}$ : i. Sektör j. Faktör Skoru

$\mathrm{VAG}_{\mathrm{j}}$ : j. Faktör Varyansı Açıklama Gücü

Her yıl için genel faktöre (GF) göre yapılan sıralamayla bir sonraki yılın takipteki krediler rasyosuna göre yapılan sektör sıralamasıyla karşılaştırılmak üzere Tablo 9'da sunulmuştur. 
2016-2019 döneminde takipteki krediler rasyosuna göre sıralamada en iyi performans gösteren sektörlerin; "Finansal Aracıllk ve Sigorta Faaliyetleri (finsig), Motorlu Araçlar ve Bunların Parça ve Aksesuarları (motorluaraç), Haberleşme (bililet), Kağıt Hammade ve Kağıt Ürünleri İmalatı (kağıt), Kimya ve Kimya Ürünleri ile Sent. Lif San. (kimya/eczacılık) olduğu görülmektedir. Faktör Analizi sonuçlarına göre yapılan sıralamalarda da Finansal Aracılık (finsig), Kimya ve Kimya Ürünleri ile Sent. Lif San. (kimya/eczacılık) ile Motorlu Araçlar ve Bunların Parça ve Aksesuarları (motorluaraç) sektörleri ilk sıralarda yer almaktadır. Her dört yıl için de elde edilen sonuçların tutarlılığı, doğru analiz yönteminin ve doğru finansal rasyoların kullanıldığının göstergesi olarak değerlendirilebilir.

Ayrıca 2015-2018 döneminde İnşaat sektörünün analiz sonuçlarına göre sıralamanın en sonlarında yer alması, takipteki krediler rasyosuna göre yapılan sıralamada ise kademeli olarak alt sıralara kayması, analiz sonuçlarının gelecek yıllara ilişkin önsel bilgi verdiğini göstermektedir. Özellikle Elektrik Gaz ve Su Kaynakları (elekgaz) sektörünün 2015 ve 2016 y1l analiz sonuçlarına göre sıralamanın sonlarındaki yeriyle takipteki krediler rasyosuna göre yapılan sıralamalardaki yeri oldukça farklılaşmaktadır. Ancak 2017 ve 2018 yılı analiz sonuçlarına göre yine sıralamanın alt sıralarında yer alan sektörün, yıllar itibariyle artan takipteki krediler rasyosuna bağlı olarak yapılan sıralamalarda da aşağıya doğru hareket ettiği görülmektedir. Bu saptamalar da analiz sonuçlarının sektörel gelişmelere yönelik önsel bilgi verdiğini bir kez daha teyit etmektedir. 
Tablo 9

\section{5-2018 Dönemi Sektörel Risk Derecelendirmesi}

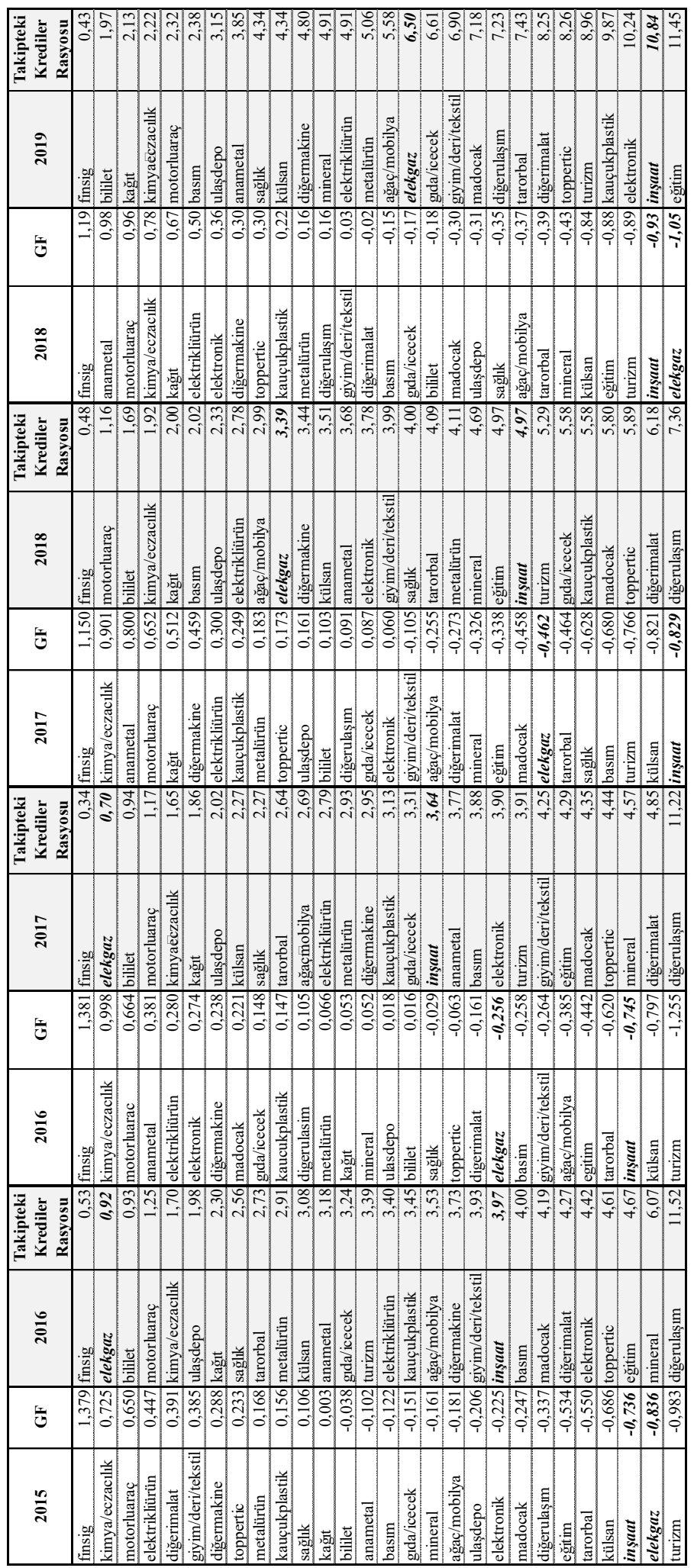




\section{Sektörel Öncü Göstergelerin Belirlenmesi}

Faktör analizi yöntemiyle dört yıllık dönem için yapılan yatay kesit analiz sonuçlarının tutarlığını değerlendirmek amacıyla, yatay kesit verilerden oluşan veri setine zaman boyutu da eklenerek panel veri analizi uygulanmıştır. Panel veri analizi kısa zaman serilerine de ekonometrik analiz yapabilme imkânı sunmaktadır (Baltagi, 2005: 9). Böylece 2013-2019 dönemi için sektörel takipteki krediler rasyoları ile sektörel finansal rasyolar arasındaki ilişkilerin yönü ve büyüklüğü tahmin edilerek, faktör analizi sonucunda yüksek açıklama gücüne sahip finansal rasyolarla örtüşüp örtüşmediği değerlendirilecektir.

\subsection{Panel Veri Analizi Yöntemi}

Zaman serisi ve yatay kesit verilerinin karmasından oluşan panel veriler, çok sayıdaki kesite ait zaman serileri veya zaman boyutuna sahip kesit veriler olarak tanımlanabilir (Grene, 2003: 612). Tablo 10'da temel doğrusal panel veri modelleri sunulmuştur:

Tablo 10

\section{Panel Veri Modelleri}

\begin{tabular}{|l|c|c|}
\hline & \multicolumn{1}{|c|}{ Sabit Etki } & \multicolumn{1}{c|}{ Rassal Etki } \\
\hline $\begin{array}{l}\text { Tek } \\
\text { Yönlï } \\
\text { Birim } \\
\text { Etki }\end{array}$ & $Y_{i t}=\left(\alpha_{i t}+\mu_{i t}\right)+\beta_{1 i t} X_{1 i t}+\ldots+\beta_{k i t} X_{k i t}+e_{i t}$ & $Y_{i t}=\alpha_{i t}+\beta_{1 i t} X_{1 i t}+\ldots+\beta_{k i t} X_{k i t}+\left(\mu_{i}+v_{i t}\right)$ \\
\hline $\begin{array}{l}\text { Tek } \\
\text { Yönlï } \\
\begin{array}{l}\text { Zaman } \\
\text { Etkisi }\end{array}\end{array}$ & $Y_{i t}=\left(\alpha_{i t}+\lambda_{i t}\right)+\beta_{1 i t} X_{1 i t}+\ldots+\beta_{k i t} X_{k i t}+e_{i t}$ & $Y_{i t}=\alpha_{i t}+\beta_{1 i t} X_{1 i t}+\ldots+\beta_{k i t} X_{k i t}+\left(\lambda_{i}+v_{i t}\right)$ \\
\hline $\begin{array}{l}\text { Cift } \\
\text { Yönlï }\end{array}$ & $Y_{i t}=\left(\alpha_{i t}+\mu_{i t}+\lambda_{i t}\right)+\beta_{1 i t} X_{1 i t}+\ldots+\beta_{k i t} X_{k i t}+e_{i t}$ & $Y_{i t}=\alpha_{i t}+\beta_{1 i t} X_{1 i t}+\ldots+\beta_{k i t} X_{k i t}+\left(\mu_{i}+\lambda_{i t}+v_{i t}\right)$ \\
\hline
\end{tabular}

i: $1,2, \ldots \ldots, N \quad t=1,2, \ldots \ldots, T$

$\mu_{i}$ : Gözlenemeyen birim etki. Zaman bağlı olmamakla birlikte kesitten kesite farklılık göstermektedir.

$v_{i t}$ : Stokastik hata terimidir. Hem zamana göre ve hem de kesite göre değişebilmektedir.

$\lambda_{t}$ : Gözlenemeyen zaman etkisi. Bireylere bağlı olmamakla birlikte zaman dilimleri arasında farklılık göstermektedir.

Tablo 10'da yer verilen modellerde i indisi birimleri (kesitleri), t indisi ise zamanı göstermektedir. Tek yönlü modellerde yalnızca gözlenemeyen birim etkinin $\left(\mu_{i}\right)$, çift yönlü modellerde ise hem birim $\left(\mu_{i}\right)$ hem de zaman etkisinin $\left(\lambda_{t}\right)$ modellere dahil edildiği görülmektedir. Sabit etki ve rassal etki modellerinde $\beta$ ile gösterilen eğim katsayıları değişmemektedir. Ancak tek yönlü birim etki modelinde her bir yatay kesit birimi için, tek yönlü zaman etkisi modelinde her bir zaman kesiti için, çift yönlü modelde ise hem yatay hem de zaman kesiti için farklı bir sabit katsayı hesaplanmaktadır (Baltagi, 2005:11-12). 
Rassal etki modellerinde ise tek yönlü modellerde iki bileşenli hata terimi, çift yönlü modellerde ise üç bileşenli hata terimi hesaplanmaktadır. Dolayısıyla sabit etki modellerinde birim ve/veya zaman etkisi sabit katsayı üzerinden, rassal etki modellerinde ise hata terimi üzerinden modele dahil edilmektedir.

Sabit etkiler modelinde katsayı tahmini yapay (dummy) değişkenler kullanılarak yapıldığından serbestlik derecesi kaybına neden olmaktadır. Bu olumsuzluğu ortadan kaldırmak için sabit etkiler modelindeki değişkenlerin ortalamaları alınmaktadır. Rassal etki modellerinde ise serbestlik derecesi kaybı yaşanmamakla birlikte modele örneklem dışındaki etkilerin de dahil edilmesine olanak sağlanmaktadır (Hsiao, 1986:33).

Panel veri modelinde birim ve/veya zaman etkisinin varlığ $\mathrm{F}$ testi ve Olabilirlik Oran testi yaygın olarak kullanılmaktadır. Bu testler sonucunda saptanan etkinin sabit mi yoksa rassal mı olduğu Hausman testi aracılığıyla saptanabilmektedir. Panel veri modellerinde temel varsayımların testleri de kurulan modellere göre farklılık göstermektedir (ayrıntılı bilgi için bkz Tatoğlu, 2016: 168-241).

\subsection{Panel Veri Analizi Uygulaması}

Faktör analizi uygulamasında sektörel risk derecelendirmesinde kontrol değişkeni olarak kullanılan bir sonraki döneme $(\mathrm{t}+1)$ ait sektörel takipteki krediler rasyoları bağımlı değişken olarak belirlenmiştir. Açıklayıcı değişkenler ise dört yıllık faktör analizi uygulamasında kullanılan 33 sektöre ait 23 finansal rasyodur. Veri seti 2013-2019 dönemi sektörel takipteki krediler rasyoları ile 2012-2018 dönemi sektörel finansal rasyoları içerecek şekilde hazırlanmış olup panel veri analizinde gecikmeli dönem (t-1) verisi kullanılmasına gerek kalmamıştır.

Panel veri regresyon modeli oluşturulurken, yatay kesit ve zaman serisi verilerinin birlikte kullanımını sağladığından yatay kesitte sektörel (birim) etkinin ve zaman serisinde yıl (zaman) etkisinin anlamlı olup olmadığı F testi ve Olabilirlik Oran (Likelihood Ratio-LR) testiyle sınanmaktadır. F ve LR testine ilişkin hipotezler, istatistik değerleri ve test edilen hipotezin kabul edilme olasılıklarına Tablo 11'de yer verilmiştir: 
Tablo 11

F Testi ve Olabilirlik Oran Testi Sonuçları

\begin{tabular}{|c|c|c|c|c|c|}
\hline \multicolumn{3}{|c|}{ F TESTI } & \multicolumn{3}{|c|}{ OLABİLIRLIIK ORAN (LR) TESTİ } \\
\hline Hipotez & $\begin{array}{c}F \text { testi } \\
\text { istatistiği }\end{array}$ & $\begin{array}{c}\text { Olasıllı } \\
\text { Değeri }\end{array}$ & Hipotez & $\begin{array}{c}\text { LR test } \\
\text { istatistiğ } i\end{array}$ & $\begin{array}{c}\text { Olasılık } \\
\text { Değeri }\end{array}$ \\
\hline $\begin{array}{l}\mathrm{H}_{0} \text { : Birim etki yoktur. } \\
\mathrm{H}_{1} \text { : Birim etki vardır. }\end{array}$ & 2,74 & 0,0000 & $\begin{array}{l}\mathrm{H}_{0} \text { : Birim etkilerin standart hataları 0'a eşittir. } \\
\text { (Klasik Model uygun) } \\
\mathrm{H}_{1} \text { : Birim etkilerin standart hataları } 0 \text { 'a eşit } \\
\text { değildir. }\end{array}$ & 12,05 & 0,0003 \\
\hline $\begin{array}{l}\mathrm{H}_{0} \text { : Zaman etkisi yoktur. } \\
\mathrm{H}_{1} \text { : Zaman etkisi vardır. }\end{array}$ & 6,71 & 0,0000 & $\begin{array}{l}\mathrm{H}_{0} \text { : Zaman etkilerin standart hataları 0'a eşittir. } \\
\text { (Klasik Model uygun) } \\
\mathrm{H}_{1} \text { : Zaman etkilerin standart hataları 0'a eşit } \\
\text { değildir. }\end{array}$ & 17,16 & 0,0000 \\
\hline & & & $\begin{array}{l}\mathrm{H}_{0} \text { : Birim veya zaman etkilerinin en az birinin } \\
\text { standart hataları 0'a eşittir. } \\
\mathrm{H}_{1} \text { : Birim veya zaman etkilerinin standart hataları } \\
\text { 0'a eşit değildir. (İki Yönlü Model uygun) }\end{array}$ & 34,94 & 0,0000 \\
\hline
\end{tabular}

F testi ve LR testi olasılık değerlerine göre veri setine ilişkin birim ve zaman etkilerinin olmadığ şseklindeki H0 hipotezleri reddedilmekte, böylece hem birim hem de zaman etkisinin varlığ kabul edilerek "Klasik Model”'in uygun model olmadığ sonucuna ulaşılmaktadır. Bu sonucun teyit edilmesi amacıyla LR testiyle birim veya zaman etkilerinin varlığı diğer bir deyişle “İki Yönlü Model”in uygunluğu sınanmış, H0 hipotezi düşük olasılık değeriyle reddedilmiş ve “İki yönlü Model’in uygun olduğuna karar verilmiştir.

Dolayısıyla sektörel takipteki krediler rasyosundaki gelişimi açıklarken sektörel finansal rasyoların yanısıra sektörlere (birim etki) ve yıllara (zaman etkisi) ilişkin etkilerin modele dahil edilmesi gerektiği sonucuna ulaşılmıştır. Bu sonuç önsel beklentilerimizle uyumludur. Çünkü bir sektöre ait takipteki krediler rasyosu, o sektörün dinamiklerine göre şekilleneceğinden sektörler arası farklılaşma beklentiler dahilindedir. Yine aynı şekilde zaman etkisinin modele dahil edilmesiyle yıllar itibariyle değişkenlik gösteren makroekonomik koşullar ile sektörel takipteki krediler rasyoları arasındaki ilişklerin saptanabilmesi açısından da oldukça kritiktir.

Birim ve zaman etkileri için "sabit" ve/veya "rassal" etki modellerinden hangisinin kullanılacağına Hausman testi ile karar verilmektedir (Green, 2002:301). Hausman testi, tanımlama hatasını sınamak için geliştirilen bir spesifikasyon testidir ve sabit etkiler modeli parametre tahmincileri ile rassal etkiler modeli parametre tahmincileri arasındaki farkın istatistiksel 
olarak anlamlı olup olmadığı test edilmektedir. Bu testte sabit etki modelinin tutarlı ve yansız olduğu varsayılmakta ve rassal etki tahmincisinin geçerli olduğu şeklinde kurulan temel hipotez test edilmektedir (Baltagi, 2005:66). Birim ve zaman etkisi için uygulanan Hausman testi sonuçları Tablo 12'de sunulmuştur:

Tablo 12

Hausman Testi Sonuçları

\begin{tabular}{|l|c|c|l|}
\hline Hipotez & $\begin{array}{c}\text { Hausman } \\
\text { test } \\
\text { istatistiği }\end{array}$ & $\begin{array}{c}\text { Olasılık } \\
\text { Değeri }\end{array}$ & \multicolumn{1}{c|}{ Sonuç } \\
\hline $\begin{array}{l}\mathrm{H}_{0} \text { : Birim etki için "Rassal } \\
\text { etki" tahmincisi geçerli. }\end{array}$ & 50.99 & 0.000 & $\begin{array}{l}\text { Olasılık değeri \%5'in altında } \\
\text { olduğu için } \mathrm{H}_{0} \text { hipotezi } \\
\text { reddedilmiştir. Birim etki için } \\
\text { "Sabit etki" tahmincisi geçerli. }\end{array}$ \\
$\begin{array}{l}\mathrm{H}_{1} \text { : Birim etki için "Sabit etki" } \\
\text { tahmincisi geçerli. }\end{array}$ & $-4,89$ & - & $\begin{array}{l}\text { Verinin uygun olmamasi nedeniyle } \\
\text { "zaman etkisi" için test } \\
\text { yapilamamiştır. }\end{array}$ \\
\hline $\begin{array}{l}\mathrm{H}_{0} \text { : Zaman etkisi için "Rassal } \\
\text { etki" tahmincisi geçerli. }\end{array}$ & $\begin{array}{l}\mathrm{H}_{1} \text { : Zaman etkisi için "Sabit } \\
\text { etki" tahmincisi geçerli. }\end{array}$ & \multicolumn{2}{|l}{} \\
\hline
\end{tabular}

Hausman testi sonuçlarında birim etki için "sabit etki" tahmincisinin geçerli olduğu sonucuna ulaşılmış, ancak zaman etkisi için dönem sayısının (T) kısa ve açıklayıcı değişken sayısından (N) oldukça az olması nedeniyle test sonucuna ulaşılamamıştır. Hausman testinde yalnızca $\mathrm{H}_{0}$ hipotezi altında kovaryans matrisi pozitif yarı tanımlıdır (Hausman, Ruud, 1987: 83104). Test istatistiğinin negatif hesaplanması pozitif yarı tanımlı olmayan kovaryans matrisinin bir sonucudur ve her zaman kısa örneklerden kaynaklanan bir sorun olmayabilir. Ancak test istatistiğinin negatif olması $\mathrm{H}_{0}$ ’’n reddedilmesi için geçerli neden değildir. (Schreiber, 2008: 16)

Hausman testi iki yönlü modellerin geçerli olduğu durumda uygun tahminciye karar vermek için de genişletilebilmektedir (Tatoğlu, 2016:188). Bu noktadan hareketle birim etkinin sabit olduğu sonucuna da ulaşıldığından, "zaman etkisinin sabit" ve "zaman etkisinin rassal” kabul edildiği iki ayrı model kurularak uygun tahminciye karar vermek üzere Hausman testi yapılmıştır. "Birim etkisi sabit-zaman etkisi sabit (İki yönlü sabit etkiler)" model gölge değişkenli EKK ile "Birim etkisi sabit-zaman etkisi rassal" model Genelleştirilmiş EKK ile tahmin edilmiştir. Hausman testi sonucunda 0,025 olasılık değeriyle "Birim etkisi sabit-zaman etkisi sabit (İki yönlü sabit etkiler)" modelinin uygun model olduğu sonucuna ulaşılmıştır. 
Sabit etkiler modelinin varsayımları kapsamında otokorelasyon Baltagi-Wu ve Değiştirilmiş Durbin Watson testiyle, birimlere göre değişen varyans (heteroscedasticity) değiştirilmiş Wald testiyle ve birimler arası korelasyon ise Pesaran testiyle incelenmiştir. Tablo 13 'te sabit etkiler modelinin varsayımlarına ilişkin test sonuçları özetlenmiştir.

Tablo 13

Model Varsayımlarının Test Sonuçları

\begin{tabular}{|c|c|c|c|c|}
\hline $\begin{array}{c}\text { Model } \\
\text { Varsayımları }\end{array}$ & Hipotez & $\begin{array}{l}\text { Test ve Test } \\
\text { İstatistiği }\end{array}$ & $\begin{array}{c}\text { Olasılık } \\
\text { Değeri }\end{array}$ & Sonuç \\
\hline $\begin{array}{l}\text { Otokorelasyon } \\
\text { yoktur. }\end{array}$ & $\begin{array}{l}\mathrm{H}_{0}: \\
\text { Otokorelasyon } \\
\text { yoktur. } \\
\mathrm{H}_{1}: \text { Otokorelasyon } \\
\text { vardır. }\end{array}$ & $\begin{array}{l}\text { Değiştirilmiş } \\
\text { Bhargava ve diğ. } \\
\text { Durbin-Watson = } \\
1,1371755 \\
\text { Baltagi-Wu LBI = } \\
1,7751901\end{array}$ & & $\begin{array}{l}\text { Her iki test istatistiği için } \\
\text { olasıllik değeri } \\
\text { verilmemekte, genel } \\
\text { olarak 2'nin altındaki } \\
\text { değerlerin } \\
\text { otokorelasyonun } \\
\text { varlığına işaret ettiği } \\
\text { kabul edilmektedir } \\
\text { (Tatoğlu, 2016: s.226). }\end{array}$ \\
\hline $\begin{array}{l}\text { Değişen varyans } \\
\text { yoktur. }\end{array}$ & $\begin{array}{l}\mathrm{H}_{0} \text { : Değişen } \\
\text { varyans yoktur. } \\
\mathrm{H}_{1} \text { : Değişen } \\
\text { varyans vardır. }\end{array}$ & $\begin{array}{l}\text { Değiştirilmiş } \\
\text { testi=1276,25 }\end{array}$ & 0,0000 & $\begin{array}{l}\text { Olasilık değeri \%5'in } \\
\text { altında olduğu için } \mathrm{H}_{0} \\
\text { hipotezi reddedilmiştir. } \\
\text { Değişen varyans var. }\end{array}$ \\
\hline $\begin{array}{l}\text { Birimler aras1 } \\
\text { korelasyon yoktur. }\end{array}$ & $\begin{array}{l}\mathrm{H}_{0}: \text { Birimler aras1 } \\
\text { korelasyon } \\
\text { yoktur. } \\
\mathrm{H}_{1} \text { : Birimler aras1 } \\
\text { korelasyon vardır. }\end{array}$ & Pesaran test $=3,387$ & 0,0007 & $\begin{array}{l}\text { Olasilık değeri } \% 5^{\prime} \text { in } \\
\text { altında olduğu için } \mathrm{H}_{0} \\
\text { hipotezi reddedilmiştir. } \\
\text { Birimler } \\
\text { korelasyon var. }\end{array}$ \\
\hline
\end{tabular}

Model varsayımlarına ilişkin test sonuçlarına göre modelde otokorelasyon, değişen varyans ve birimler arası korelasyonun varlığı saptanmış, dolayısıyla modele ilişkin hiçbir varsayımın geçerli olmadığı sonucuna ulaşıılmıştır.

Modelde heteroskedasite, otokorelasyon veya birimler arası korelasyondan en az biri varsa ya parametre tahminlerine dokunmadan standart hatalar düzeltilmeli (dirençli standart elde edilmeli) veya model uygun yöntemlerle tahmin edilmelidir. Modelde heteroskedasite, otokorelasyon veya birimler arası korelasyondan en az biri varsa büyük örneklerde tutarsızlığa neden olmamakta ancak etkinliği bozmaktadır. Standart hataların t ve F istatistiklerinin, $\mathrm{R}^{2}$ 'nin ve güven aralıklarının geçerliliği ortadan kalkmaktadır. Heteroskedastisite, otokerelasyon ve birimler arası korelasyonun varlığında Parks-Kmenta, Beck-Katz, Driscoll ve Kraay dirençli tahminciler verir. Ancak örneklem sayısı dönem sayısından fazla $(\mathrm{N}>\mathrm{T})$ olduğunda "Driscoll ve Kraay 
tahmincisi” güçlü bir tahmincidir (Tatoğlu; 2016: 287). Driscoll ve Kraay’ın yöntemi yatay kesit ortalamaları serisi için Newey-West türü düzeltme yapmakta ve bu şekilde düzeltilmiş standart hata tahminleri yatay kesit boyutu N'den bağımsız olarak kovaryans matris tahmincilerinin tutarlılı̆̆ını garantilemekle birlikte dirençli standart hatalar üretmektedir (Tatoğlu, 2016: 276).

Diğer taraftan Johnston ve Dinardo (1997: 403) sabit etkiler modelinin diğer açıklayıcı değişkenlerle ilişkili sabit zaman faktörlerinin hepsinin ölçülebildiğinden emin olmadıkça rassal etkiler modeline tercih edilmemesi gerektiğini ifade etmektedir. Çünkü rassal etkiler modeli, modele örneklem dışındaki etkilerin de dahil edilmesine olanak sağlamaktır. Gerçekte ne sabit etki tahmincileri ne de rassal etkiler tahmincileri mükemmel değildir. Bunun en önemli nedenini; rassal etki tahmincisinin gerçek etkinin üzerinde tahminler vermesi, buna karşılık sabit etkiler tahmincisinin ise gerçek etkinin altında sapmalı tahminler vermesi oluşturmaktadır (Johnston, Dinardo, 1997: 403). Sektörel takipteki krediler rasyosunu etkileyebilecek birçok makro, mikro veya sektörel değişken bulunabilir. Bu değişkenlerin tamamının modele dahil edilmesi mümkün değildir. Ancak bu analizde amaç sektörel takipteki krediler rasyolarının tahmin edilmesi değil, sektörel takipteki krediler rasyolarıyla finanasal rasyolar arasındaki ilişklerin araştırılmasıdır.

Bu nedenle aşağıda yer verilen model, iki yönlü sabit etkilerle "Gölge Değişkenli EKK”, iki yönlü sabit etkiler ve rassal etkilerle "Driscoll ve Kraay" yöntemiyle tahmin edilmiş ve elde edilen sonuçlar Tablo 14’te sunulmuştur.

Takipteki Krediler Rasyosu $_{\text {it }}=\beta_{0}+\beta_{1} \mathrm{~L} 1_{\text {it- } 1}+\beta_{2} \mathrm{~L} 2_{\text {it- } 1}+\beta_{3} \mathrm{~L} 3_{\text {it }-1}+\beta_{4} \mathrm{~L} 5_{\mathrm{it}-1}+\beta_{5} \mathrm{D} 1_{\text {it-1 }}+\beta_{6} \mathrm{D} 2_{\mathrm{it}-1}+$ $\beta_{7} \mathrm{D} 3_{\text {it-1 }}+\beta_{8} \mathrm{D} 5_{\text {it-1 }}+\beta_{9} \mathrm{D} 7_{\text {it-1 }}+\beta_{10} \mathrm{D} 8_{\text {it-1 }}+\beta_{11} \mathrm{~K} 2_{\text {it- } 1}+\beta_{12} \mathrm{~K} 4_{\text {it-1 }}+\beta_{13} \mathrm{~K} 5_{\text {it-1 }}+\beta_{14} \mathrm{~K}_{\text {it-1 }}+\beta_{15} \mathrm{~K} 9_{\text {it- } 1}+$ $\beta_{16} \mathrm{M}_{\text {it-1 }}+\beta_{17} \mathrm{M} 14_{\text {it- } 1}+\beta_{18} \mathrm{M} 17_{\text {it- } 1}+\beta_{19} \mathrm{~B} 1_{\text {it }-1}+\beta_{20} \mathrm{~B} 2_{\text {it }-1}+\beta_{21} \mathrm{~B} 5_{\text {it }-1}+\beta_{22} \mathrm{~B} 8_{\text {it }-1}+\beta_{23} \mathrm{~B} 9_{\text {it }-1}+\beta_{24} 2014$ $+\beta_{25} 2015+\beta_{26} 2016+\beta_{27} 2017+\beta_{28} 2018+\beta_{29} 2019+\varepsilon_{i t}$ 
Tablo 14

Model Tahmin Sonuçları

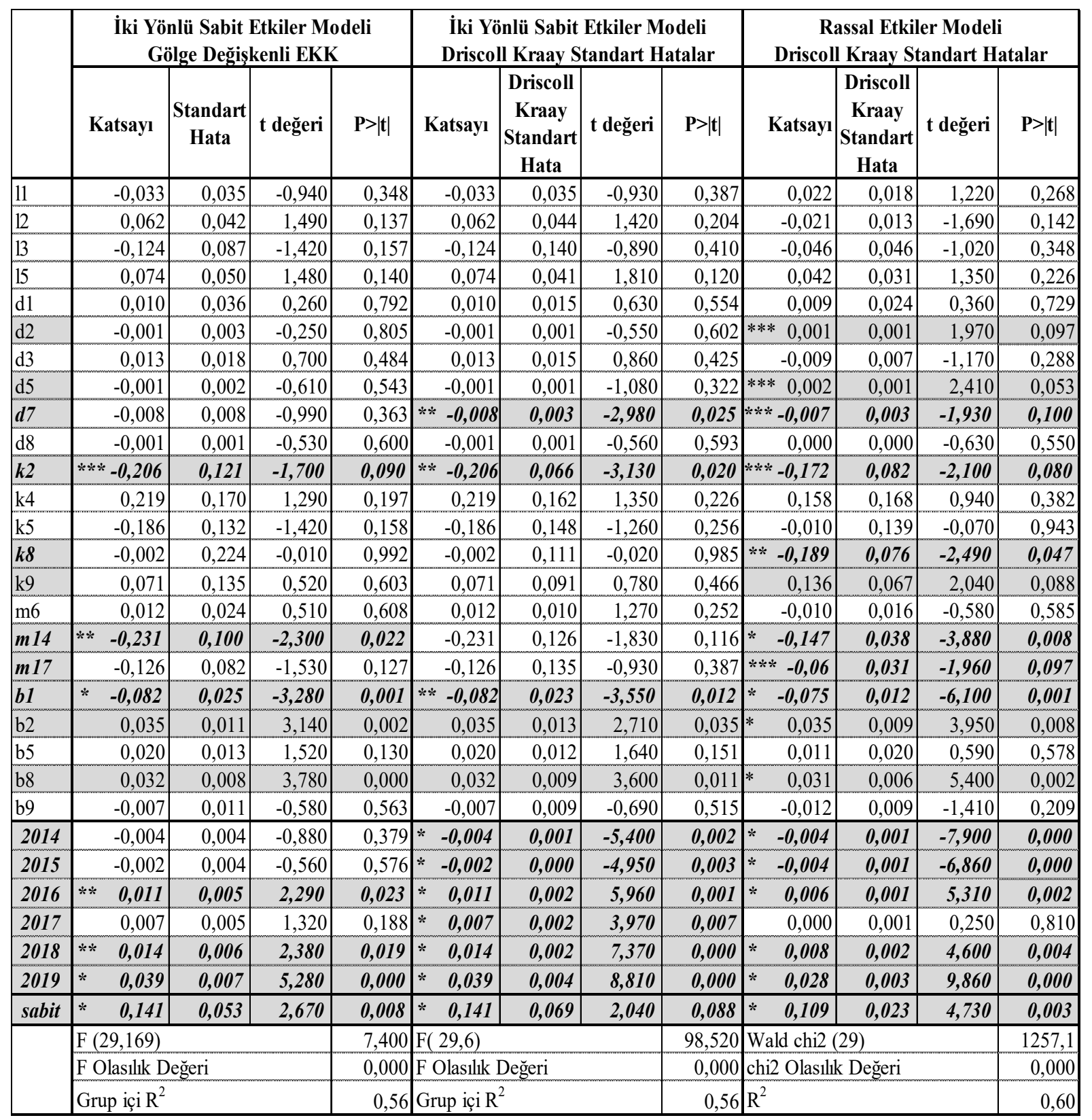

(*) $\% 1,(* *) \% 5,(* * *) \% 10$ anlamlllık düzeyinde istatistiki olarak geçerlidir.

İki yönlü sabit etkiler modelinin Gölge Değişkenli EKK’yla tahmini ile Driscoll Kraay Standart Hatalar tahmini karşılaştırıldığında; F testine göre iki modelin de geçerli olduğu, tahmin edilen katsayıların ve açıklama güçlerinin yüzde 56 düzeyinde eşit olduğu ancak katsayılara ilişkin standart hataların farklılaştığı gözlenmektedir. Buna bağlı olarak Driscoll Kraay yöntemiyle elde edilen tahmin sonuçlarında istatistiki olarak anlamlı olan açıklayıcı değişken sayısı artmıştır. 
Artışta özellikle zaman etkisini temsil eden yıllara ait katsayıların tamamının istatistiki olarak anlamlı hale gelmesi dikkat çekmektedir. Rassal etkiler tahmincisiyle tahmin edilen modele ait Wald testine göre model geçerli ve açıklama gücü yüzde 60 düzeyindedir. İstatistiki olarak anlamlı bulunan en fazla değişken de rassal etki tahmincisiyle elde edilmiştir.

Modelde bağımlı değişken sektörlere ait takipteki krediler rasyosu açıklayıcı değişkenler ise sektörel finansal rasyolardır. Önceki bölümde yer verilen faktör analizinde sektörel finansal rasyolar kullanılarak sektörel risk derecelendirmesi gerçekleştirilmişti. Söz konusu finansal rasyoların düzeyi sektörlerin risklilik düzeyine göre sıralanmasında sektörleri pozitif yönde etkilemekteydi. Dolayısıyla bu finansal oranlardaki pozitif yöndeki değişim sektörlerin olumlu yönde gelişimine işaret etmekte ve takipteki krediler rasyolarıyla ters yönlü ilişkisi olması beklenmektedir. Bu noktadan hareketle, tahmin sonuçlarında katsayıları istatistiki olarak anlamlı bulunan finansal rasyoların negatif katsayıya sahip olması önsel beklentilerimizle örtüştügünü söylemek mümkündür. İstatistiki olarak anlamlı olan “d2, d5, k9, b2 ve b8” rasyolarının katsayıları önsel beklentilerimizle örtüşmemekte ancak “d7, k2, k8, m14, m17 ve b1” rasyolarının katsayıları önsel beklentilerimize uymaktadır. Bu sonuçlara göre tüm sektörler için, “Özkaynak Devir Hızı (d7)”, "Ekonomik Rantabilite (k2)”, "Net Kâr/Aktif Toplamı (k8)”, “Özkaynak/Toplam Aktif (m14)", "Uzun Vadeli Yabancı Kaynaklar/Pasif Toplamı (m17), "Aktif Büyüme Hızı (b1)" rasyoları yükseldikçe takipteki krediler rasyoları azalacaktır. "Ekonomik Rantabilite (k2)”, "Net Kâr/Aktif Toplamı (k8) ve "Özkaynak/Toplam Aktif (m14)" rasyoları faktör analizi sonuçlarında son üç yılda süreklilik gösteren rasyolar arasında yer almaktadır. Dolayısıyla hem yatay kesit analiz sonuçlarında hem de yedi yıllık zaman boyutunun dahil edilmesiyle yapılan panel veri analiz sonuçlarında ortak rasyoların önplana çıkması, yapılan analizlerin tutarlılığı açısından oldukça memnuniyet vericidir.

Panel veri analiz sonuçlarında takipteki krediler rasyosunun değişiminde belirleyici olan rasyolar arasında saptanan Aktif Kârlılı̆̆ı (Net Kâr/Aktif Toplamı) ve Özkaynak Büyüklüğ̈̈ (Özkaynak/Toplam Aktif) rasyoları, bir firmanın finansal durumuna ilişkin değerlendirme yapılmak istendiğinde temel olarak incelenecek rasyolardan ikisidir. Saptanan üçüncü rasyo ise, Ekonomik Rantabilite' dir. Bu oran sektörlerin finansman olanaklarından yararlanabilme kabiliyetinin bir göstergesi olarak veya bütün sektörlerin aynı kredi olanaklarına ulaşabildiği varsayılırsa kullanılan kredilerin maliyetinin bir göstergesi olarak yorumlanabilecektir. Ancak gerek faktör analizinde 
gerekse panel veri analizinde kullanılan rasyoların pozitif yönlü olduğu, dolayısıyla rasyolardaki artışın sektörü olumlu yönde etkilemesi öngörülmüştü. Dolayısıyla ekonomik rantabilitedeki artış sektörün borçlanabilme kabiliyetinin bir göstergesi olarak yorumlanmaktadır. Ayrıca faktör analizi sonuçlarında yer almasa da, her üç tahmin yönteminde de istatistiki olarak anlamlı bulunan Aktif Artışı (b1)'nın da sektörel takipteki krediler rasyosu üzerinde önemli bir etkiye sahip olduğu görülmektedir. Sonuç olarak aktif kârlılığı, özkaynak büyüklüğü ve ekonomik rantabilite artışının sektörel risklilik düzeyinin saptanmasında birer öncü gösterge olarak kullanılabileceğini söylemek mümkündür.

Driscoll Kraay yöntemiyle tahmin edilen iki yönlü sabit etkiler ve rassal etkiler sonuçlarında zaman etkileri incelendiğinde, sabit etkiler modelinde inceleme dönemi kapsamındaki bütün yılların katsayısı istatistiki olarak anlamlı bulunmuş, rassal etkiler modelinde ise yalnızca 2017 yılı katsayısı istatistiki olarak anlamsız bulunmuştur. Yıllara ilişkin katsayıların Türkiye ekonomisinin büyüme rakamlarıyla birlikte değerlendirilmesini yararlı olacağ düşünülmektedir. Tablo 15'te 2014-2019 dönemi büyüme rakamları ile Driscoll Kraay yöntemiyle tahmin edilen sabit etkiler ve rassal etkiler modellerinin katsayıları verilmiştir:

Tablo 15

Türkiye Ekonomisi Büyüme Oranları ve Tahmin Edilen Zaman Etkisi Katsayıları

\begin{tabular}{|c|c|r|r|}
\hline & Büyüme & $\begin{array}{c}\text { Sabit Etkiler } \\
\text { Modeli } \\
\text { Katsayıları }\end{array}$ & $\begin{array}{c}\text { Rassal Etkiler } \\
\text { Modeli } \\
\text { Katsayıları }\end{array}$ \\
\hline $\mathbf{2 0 1 4}$ & 5,2 & $-0,004$ & $-0,005$ \\
\hline $\mathbf{2 0 1 5}$ & 6,1 & $-0,002$ & $-0,004$ \\
\hline $\mathbf{2 0 1 6}$ & 3,2 & 0,011 & 0,006 \\
\hline $\mathbf{2 0 1 7}$ & 7,5 & 0,007 & - \\
\hline $\mathbf{2 0 1 8}$ & 2,8 & 0,014 & 0,008 \\
\hline $\mathbf{2 0 1 9}$ & 0,9 & 0,039 & 0,028 \\
\hline
\end{tabular}

Tablo 15'ten de izlenebileceği üzere yüksek büyüme oranlarının yaşandığ 2014 ve 2015 yıllarında tahmin edilen katsayılar negatif işaretlidir. Dolayısıyla genel beklentilere paralel bir şekilde, yüksek ekonomik büyüme dönemlerinin sektörel takipteki krediler rasyoları üzerinde azaltıcı etkisi olduğunu söylemek mümkündür. 2017 yılında ise yüksek büyüme oranına rağmen sabit etkiler modelinde negatif bir katsayı tahmin edilmemiş, ancak yine de diğer yıllara göre oldukça düşük düzeyde bir katsayıya ulaşılmıştır. Rassal etkiler modelinde ise 2017 yılına ilişkin 
katsayı istatistiki olarak anlamsız bulunmuştur. 2016 yılında yaşanan Darbe Girişimi’nin ekonomik aktiviteyi de olumsuz yönde etkileyerek yüksek büyüme hızının yavaşlamasına neden olduğu ve bu gelişmelerin sektörel takipteki krediler rasyoları üzerinde arttırıcı yönde etkiye sahip olduğu görülmektedir. 2018 yılında 2016 yılına yakın bir büyüme oranı gerçekleşmiş, buna paralel olarak ilgili yılın katsayı da 2016 yılı düzeyine yakın bir düzeyde tahmin edilmiştir. 2019 yılında inceleme döneminin en düşük büyüme oranı gerçekleşmiş, buna bağlı olarak da katsayılarda pozitif ve inceleme dönemi içerisindeki en yüksek düzeyde tahmin edilmiştir. Sonuç olarak önsel beklentilerimiz dahilinde olan sektörel takipteki krediler rasyoları ile büyüme arasındaki negatif yönlü ilişki, tahmin sonuçlarıyla da örtüşmektedir.

\section{Sonuç}

Bankaların hem sermaye yeterlilik rasyosunun bir bileșeni olarak kredi riskinin hesaplanmasında hem de TFRS 9 uygulaması kapsamında karşılık tutarının hesaplanmasında mevzuatın getirdiği zorunluluklar haricinde içsel model kullanmaları, etkin ve kapsamlı bir kredi riski yönetimi sağlayabilmeleri açısından da oldukça yararlı olacağı değerlendirilmiştir. Bu noktadan hareketle çalışmada sektörel kredi riski iki farklı boyutuyla ele alınmıştır: Birincisi sektörlerin birbirlerine göre risklilik düzeyini ölçen bir yaklaşımla sektörel risk derecelendirmesi, ikincisi ise sektörel takipteki krediler rasyolarının gelişiminde etkili olan rasyoların belirlenerek öncü göstergelerin saptanmasıdır.

Sektörel risk derecelendirmesi tek bir zaman noktasında bütün sektörlerin birlikte değerlendirilerek, birbirlerine karşı risklilik düzeyinin ölçülmesi temel esasına dayanmaktadır. $\mathrm{Bu}$ nedenle sektörel risk derecelendirmesinde çok değişkenli yatay kesit analiz tekniklerinden faktör analizi kullanılmıştır. 2015-2018 döneminde her yıl için yapılan sektörel risk derecelendirmesi sonuçlarına göre sektörler en iyi sektörden en kötü sektöre doğru sıralanmıştır. Sektörün kredi riski düzeyini belirleyen en önemli gösterge niteliğindeki sektörel takipteki krediler rasyoları, sektörel risk derecelendirmesinin sonuçlarını değerlendirmek için kullanılmıştır.

Faktör analizi sonuçlarına göre, faktör yapı matrislerinde yoğunlaşan finansal rasyolara göre birinci faktör "kârlılık-likidite-mali yapı", ikinci faktör "devir hızı", üçüncü faktör de “büyüme” olarak adlandırılmıştır. Darbe Girişimi’nin yaşandığı 2016 yılında diğer üç yıldan farklı olarak, brüt satışlar artışı (B5) rasyosunun varyans açıklama gücü diğer yıllara göre önemli oranda artmış ve analiz döneminde ilk defa brüt satışlar artışı rasyosu birinci faktörde yoğunlaşmıştır. 
Dolayısıyla 2016 yılı özelinde yaşanan bu gelişmenin analiz sonucuna yansıması, çalışmanın giriş bölümünde yer verilen analizin makroekonomik gelişmelerin sonuçlarını da yansıtacağı yönündeki önsel beklentinin karşılandı̆̆ını göstermiştir.

Sektörel risk derecelendirmesinde ilk sıralarda yer alan sektörlerin, takipteki krediler rasyosuna göre yapılan sıralamada en iyi performans gösteren sektörler olduğu gözlenmektedir. $\mathrm{Bu}$ sonuçlar, doğru analiz yönteminin ve doğru mali rasyoların kullanıldığının göstergesi olarak değerlendirilebilir. Elektrik Gaz ve Su Kaynakları (elekgaz) ve İnşaat sektörlerinin sırasıyla bu sektörlerin takipteki krediler rasyolarındaki gelişmeler de tutarlıdır. 2015-2018 döneminde Elektrik Gaz ve Su Kaynakları (elekgaz) ve İnşaat sektörünün analiz sonuçlarına göre sıralamanın en sonlarında yer alması, takipteki krediler rasyosuna göre yapılan sıralamalarda ise bu sektörlerin kademeli olarak alt sıralara kayması, analiz yönteminin sektörel gelişmelere yönelik önsel bilgi verdiğine de işaret etmektedir.

Ayrıca BDDK 17 Eylül 2019 tarihinde Elektrik Gaz ve Su Kaynakları ve Inşaat sektörlerine ilişkin 46 milyar TL tutarındaki kredinin aslında takip hesaplarında izlenmesi gerektiği açıklanmıştır. Bu açıklamadan söz konusu iki sektörün takipteki krediler rasyosunun, bankalarca olması gereken düzeyden daha düşük bir düzeyde açıklandığı anlaşılmaktadır. Bankalarca söz konusu krediler takip hesaplarına aktarıldığında, iki sektöre ilişkin takipteki krediler rasyosu daha yüksek düzeylerde hesaplanacak ve sıralamadaki yerleri mevcut düzeyden daha alt sıralara düşecektir. Dolayısıyla BDDK tarafından yapılan açıklama "Elektrik Gaz ve Su Kaynakları” ve "İnşaat" sektörlerine ilişsin analiz sonuçlarını teyit etmiştir.

Sektörel risk derecelendirmesi kapsamında dört yıllık yatay kesit analizlerinde açıklama gücü yüksek olan rasyoların, sektörel takipteki krediler rasyolarının zaman içindeki gelişimini de açıklayıp açıklayamayacağını saptayabilmek amacıyla panel veri analizi yapılmıştır. 2013-2019 dönemi için yapılan panel veri analizinde $\mathrm{t}$ dönemine ait sektörel takipteki krediler rasyoları, $\mathrm{t}-1$ dönemine ait sekörel finansal rasyolarla açıklanmaya çalışılmıştır. Her iki analiz sonucunda anlamlı bulunan ortak rasyolar aşağıda verilmiştir:

- Ekonomik Rantabilite (K2: (Vergi Öncesi Kâr+Finansman Giderleri)/Pasif Toplamı)

- $\quad$ Net Kâr / Aktif Toplamı (K8)

- Özkaynaklar/Aktif Toplamı (M14) 
Hem sektörel farklılaşmayı hem de sektörel takipteki krediler rasyosundaki gelişmeleri açıklamada başarılı olan bu rasyoların birer öncü gösterge olarak kullanılabileceğini değerlendirilmiştir. Faktör analizinde açıklama gücü yüksek olarak belirlenen rasyolardan "likidite rasyoları"na ait katsayılar, panel veri analizinde anlamlı bulunmamıştır. Dolayısıyla "likidite rasyoları"nın sektörel farklılaşmayı açıklamada yüksek başarıya sahip olduğu, ancak sektörel takipteki krediler rasyolarının gelişimini açıklamada anlamlı olmadığı görülmüştür. Diğer taraftan faktör analizi sonuçlarında yer almasa da, her üç tahmin yönteminde de istatistiki olarak geçerli bulunan Aktif Artışı (B1)'nın da sektörel takipteki krediler rasyosunun gelişiminde anlamlı bir etkiye sahip olduğu saptanmıştır.

Ayrıca panel veri analiz sonuçlarında zaman etkisinin varlığ 1 ve yıllara ilişkin katsayılar da istatistiki olarak anlamlı bulunmuştur. Ekonomik büyüme rakamlarıla birlikte değerlendirilen bu katsayılar, sektörel takipteki krediler rasyolarıyla ekonomik büyüme arasında beklenen negatif yönlü ilişkiyi de teyit etmiştir.

Faktör analizinde açıklama gücü yüksek olarak belirlenen rasyolardan likidite rasyolarına ait katsayılar, panel veri analizinde anlamlı bulunmamıştır. Dolayısıyla likidite rasyolarının sektörel farklılaşmayı açıklamada yüksek başarıya sahip olduğu, ancak sektörel takipteki krediler rasyolarının zaman içindeki gelişimini açıklamada anlamlı olmadığı görülmüştür.

Öncü gösterge olarak belirlenen rasyoların, hangi sektörde faaliyet gösterirse göstersin bir firmanın mali yapısının değerlendirilmesinde kullanılacak en temel rasyolar olduğu aşikârdır. Bir firmanın yüksek oranda özkaynağa sahip olması (M14), aktif kârlılığının yüksek olması (K8) ve borçlanma olanaklarına erişebiliyor olması (K2) o firmanın kredibilitesinin yüksek olduğunu gösterir. Dolayısıyla sektörel analizde de bu temel rasyoların anlamlı bulunması yapılan analizin sağlıklı sonuçlar ürettiğinin bir göstergesidir. Türkiye Bankalar Birliği Risk Merkezi’nden alınan bankacılık sektörü verilerinin, Sanayi ve Teknoloji Bakanlığı veri sisteminden alınan sanayi sektörü verileriyle açıklanmaya çalışıldığı göz önüne alınırsa, elde edilen sonuçlar, banka ve firma özelinde veri toplayan bu iki farklı veri kaynağının oldukça güvenilir olduğunu da teyit etmiştir.

Sonuç olarak, çalışmada ele alınan sektörel risk derecelendirmesi ve sektörel öncü gösterge yaklaşımlarının kredi risk politikalarının belirlenmesinden sektörel temerrüt olasılıklarının hesaplanmasına kadar birçok alanda etkin birer risk yönetimi aracı olarak kullanılabileceği gibi 
içsel modellere entegre edilebilecek yapılarıyla da bu yöndeki çalışmalara katkı sağlayabileceği değerlendirilmektedir. 


\section{Kaynakça}

Apan, M. \& İslamoğlu, M. (2018). Determining the Impact of Financial Characteristics on Firm Profitability: An Empirical Analysis on Borsa Istanbul Energy Firms. Wseas Transactions on Business and Economics, 15, 547-559.

Atan, M. (2002). Türkiye Bankacılık Sektörü İçin Alternatif Bir Risk Derecelendirme Modeli. Ekonomik Yaklaşım, 18(62).

Baltagi, B. H. (2005). Econometric Analysis of Panel Data. West Sussex: John Wiley \& Sons Ltd.

BDDK (2005). 10 Soruda Yeni Basel Sermaye Uzlaşısı. Alınan Yer,

https://www.bddk.org.tr/ContentBddk/dokuman/duyuru_basel_0001_38.pdf

BDDK (2007). Basel II, Ekonomik Yansımaları ve Geçiş Süreci (Çalışma Raporu). Alınan Yer, https://www.bddk.org.tr/ContentBddk/dokuman/duyuru_basel_0001_46.pdf

BDDK (2019). 17.09.2019 Tarihli Basın Açıklaması. Alınan Yer, https://www.bddk.org.tr/ContentBddk/dokuman/duyuru_0729_01.pdf

Çolak, M. S. (2019). Bilançolara Yeni Bir Bakış: Reel Sektör Firmaları İçin Finansal Risk Endeksi. TCMB Çalışma Tebliğleri, 19/04.

Demirci, N. S. (2017). İmalat sanayi Sektöründe Kârlılığın Belirleyicileri: TCMB Sektör Bilançolarıyla Panel Veri Analizi (1996-2015). Ege Akademik Bakış, 17(3).

Erdoğan, S. \& Karaca, S. S. (2018). Türk Bankacılık Sektörünün 2009-2016 Dönemi CAMELS Derecelendirme Sistemi ile Performans Analizi. Journal of International Management, Educational and Economics Perspectives, 6(3), 23-39.

Greene, H. W. (2002). Econometric Analysis. (5th Edition), New Jersey, Prentice Hall.

Gündoğdu, A. (2017). Türkiye'de Mevduat Bankalarının CAMELS Analizi. Bankacılık ve Finansal Araştırmalar Dergisi, 4(2): 26-43.

Hausman, J. A. \& Ruud P. A. (1987). Specifying and testing econometric models for rank-ordered data. Journal of Econometrics, 34, 83-104.

Hsiao, C. (1986). Analysis of Panel Data. (1th Edition), Cambridge: Cambridge University Press.

İltaş, Y. (2016). Türkiye Cumhuriyet Merkez Bankası Sektör Bilançolarını Kullanarak İşletme Sermayesi Gereksinimini Etkileyen Değişkenler Üzerine Bir Analiz: 1996-2013. Erciyes Üniversitesi, İktisadi ve İdari Bilimler Fakültesi Dergisi, 48.

Johnston, J. \& Dinardo, J. (1997). Econometric Methods (4th edition). USA: McGraw-Hill.

Kılıç, M. \& Güler, B. (2019). Borsa İstanbul'a (BİST) Kayıtlı Lojistik Firmalarının Kârlılık Belirleyicileri. Kahramanmaraş Sütçü Imam Üniversitesi İktisadi ve İdari Bilimler Fakültesi Dergisi, 9(1), 69-82. 
Kılıçkaplan, S. (2019). Indeks Sayıları Kuramı ve Uygulamaları, İstatistiğe Giriş I, Ankara: Gazi Kitabevi.

Öcal, F. S. \& Akın, F. (2018). TCMB İmalat Sanayi Sektörel Bilançoları Kullanılarak İktisadi Parametrelerin Sermaye Yapısına Etkisi Üzerine Bir Uygulama. Akademik Hassasiyetler, 5(10). Alinan Yer, https://atif.sobiad.com/index.jsp?modul=makaleoruntule\&id=AWvRHFCxyZgeuuwfSK3v.

Screiber, S. (2008). The Hausman test statistic can be negative even asymptotically. Goethe University

Frankfurt, http://econ.schreiberlin.de/papers/schreiber_hausmantest aug2008.pdf

Tatlıdil, H. (2002). Uygulamalı Çok Değişkenli İstatistiksel Analiz, Ankara: Akademi Matbaası.

Tatoğlu, F. Y. (2016). Panel Veri Ekonometrisi (3. baskı). İstanbul: Beta Basım Yayım Dağıtım.

TCMB (2017). Sektör Bilançoları (2014-2016). İstatistik Genel Müdürlüğü, Reel Sektör Verileri Müdürlügüü, Sunuş, Alınan Yer, http://www3.tcmb.gov.tr/sektor/2017/Raporlar/sunus.pdf

Uslu, A. (2019). Türkiye'deki Yabancı Sermayeli Bankaların CAMELS Analizi ile Performanslarının Ölçümü. Muhasebe ve Finansman Dergisi, 82.

Tosuner, A., Aydoğan, E. M. \& Pekkaya S. (2002). Türk Bankacılık Sisteminde Finansal Risk Analizi. Iktisat, Işletme ve Finans Dergisi, 17(197), 47-67.

https://gbs.sanayi.gov.tr/

https://www.riskmerkezi.org/tr/istatistikler/ 